\begin{tabular}{|l|l|}
\hline and & $\begin{array}{l}\text { This paper is made available in accordance with Elsevier publisher policies. } \\
\text { Please cite the original published version only using the following reference: }\end{array}$ \\
& $\begin{array}{l}\text { DOWSON M, PEGG I, HARRISON D, DEHOUCHE Z, 2012 } \\
\text { Predicted and in-situ performance of a solar air collector incorporating a translucent granular } \\
\text { aerogel cover, Energy and Buildings, volume 49, issue C, pp 173-187 }\end{array}$ \\
& $\begin{array}{l}\text { Link to official URL: } \\
\text { http://dx.doi.org/10.1016/i.enbuild.2012.02.007 }\end{array}$ \\
\hline
\end{tabular}




\title{
Predicted and In-Situ Performance of a Solar Air Collector Incorporating a Translucent Granular Aerogel Cover
}

\author{
Mark DOWSON $^{1,2}$, Ian PEGG ${ }^{2}$, David HARRISON ${ }^{1}$ and Zahir DEHOUCHE ${ }^{1}$ \\ 1 - School of Engineering and Design, Brunel University, London, UB8 3PH, UK \\ 2 - Buro Happold Ltd, 17 Newman Street, London, W1T 1PD, UK
}

\begin{abstract}
There is an opportunity to improve the efficiency of flat plate solar air collectors by replacing their conventional glass covers with lightweight polycarbonate panels filled with high performance aerogel insulation. The in-situ performance of a $5.4 \mathrm{~m}^{2}$ solar air collector containing granular aerogel is simulated and tested. The collector is incorporated into the external insulation of a mechanically ventilated end terrace house, recently refurbished in London, UK. During the 7 day test period, peak outlet temperatures up to $45^{\circ} \mathrm{C}$ are observed. Resultant supply and internal air temperatures peak at $25-30^{\circ} \mathrm{C}$ and $21-22^{\circ} \mathrm{C}$ respectively. Peak efficiencies of $22-36 \%$ are calculated based on the proposed design across a range of cover types. Measured outlet temperatures are validated to within $5 \%$ of their predicted values. Estimated outputs range from $118-166 \mathrm{kWh} / \mathrm{m}^{2} /$ year for collectors with different thickness granular aerogel covers, compared to $110 \mathrm{kWh} / \mathrm{m}^{2} /$ year for a single glazed collector, 140 $\mathrm{kWh} / \mathrm{m}^{2} /$ year for a double glazed collector and $202 \mathrm{kWh} / \mathrm{m}^{2} /$ year for a collector incorporating high performance monolithic aerogel. Payback periods of 9-16 years are calculated across all cover types. An efficiency up to $60 \%$ and a payback period as low as 4.5 years is possible with an optimised collector incorporating a $10 \mathrm{~mm}$ thick granular aerogel cover.
\end{abstract}

\section{Keywords}

Silica aerogel; granular aerogel; flat plate collector; solar air heater; transparent insulation; domestic retrofit; mechanical ventilation; heat recovery

\section{Corresponding Author}

Mark Dowson, mark.dowson@,burohappold.com

Mobile: (+44) 07706260523

Office: (+44) 02079279700 


\section{Nomenclature}

$\mathrm{A}_{\mathrm{c}} \quad$ Collector area $\left(\mathrm{m}^{2}\right)$

$\mathrm{A}_{\mathrm{d}} \quad$ Exposed area of ductwork $\left(\mathrm{m}^{2}\right)$

$\mathrm{C}_{\mathrm{p}} \quad$ Specific heat capacity $(\mathrm{J} / \mathrm{kg} \mathrm{K})$

$\mathrm{D}_{\mathrm{h}} \quad$ Hydraulic diameter $(\mathrm{m})$

$\mathrm{F}_{\mathrm{R}} \quad$ Heat removal factor

F' Collector efficiency factor

F' Collector flow factor

$\mathrm{H} \quad$ Collector height $(\mathrm{m})$

H' Average cavity height (m)

$\mathrm{h}_{\mathrm{c}} \quad$ Convection coefficient $\left(\mathrm{W} / \mathrm{m}^{2} \mathrm{~K}\right)$

$\mathrm{h}_{\mathrm{r}} \quad$ Radiation coefficient $\left(\mathrm{W} / \mathrm{m}^{2} \mathrm{~K}\right)$

$\mathrm{h}_{\mathrm{w}} \quad$ Wind coefficient $\left(\mathrm{W} / \mathrm{m}^{2} \mathrm{~K}\right)$

k Thermal conductivity $(\mathrm{W} / \mathrm{m} \mathrm{K})$

$\mathrm{L} \quad$ Cube root of house volume (m)

$\mathrm{Nu} \quad$ Nusselt number

Pr Prandtl number

QU Useful energy (W)

$\mathrm{R}$ Thermal resistance $\left(\mathrm{m}^{2} \mathrm{~K} / \mathrm{W}\right)$

Re Reynolds number

S Solar irradiance $\left(\mathrm{W} / \mathrm{m}^{2}\right)$

$\mathrm{T}_{\mathrm{a}} \quad$ Ambient temperature $\left({ }^{\circ} \mathrm{C}\right)$

$\mathrm{T}_{\text {inside }}$ Inside temperature of house $\left({ }^{\circ} \mathrm{C}\right)$

$\mathrm{T}_{\mathrm{i}} \quad$ Collector inlet temperature $\left({ }^{\circ} \mathrm{C}\right)$

$\mathrm{T}_{\mathrm{fm}} \quad$ Mean fluid temperature $\left({ }^{\circ} \mathrm{C}\right)$

$\mathrm{T}_{\mathrm{L}} \quad$ Average air temperature lost to the environment $\left({ }^{\circ} \mathrm{C}\right)$

$\mathrm{T}_{\mathrm{o}} \quad$ Collector outlet temperature $\left({ }^{\circ} \mathrm{C}\right)$

$\mathrm{T}_{\mathrm{pm}} \quad$ Mean plate temperature $\left({ }^{\circ} \mathrm{C}\right)$

$\mathrm{U}_{\text {Back }}$ Back heat loss coefficient $\left(\mathrm{W} / \mathrm{m}^{2} \mathrm{~K}\right)$

$\mathrm{U}_{\mathrm{d}} \quad$ Loss coefficient of $\operatorname{duct}\left(\mathrm{W} / \mathrm{m}^{2} \mathrm{~K}\right)$

$\mathrm{U}_{\text {front }}$ Front heat loss coefficient $\left(\mathrm{W} / \mathrm{m}^{2} \mathrm{~K}\right)$

$\mathrm{U}_{\mathrm{L}}$ Overall heat loss coefficient $\left(\mathrm{W} / \mathrm{m}^{2} \mathrm{~K}\right)$

$\mathrm{V}_{\mathrm{w}} \quad$ Wind velocity $(\mathrm{m} / \mathrm{s})$

$\mathrm{V}$ Total volume of dwelling $\left(\mathrm{m}^{3}\right)$

W Collector width (m)

\section{Symbols}

$\begin{array}{ll}\alpha & \text { Plate absorptance } \\ \beta & \text { Collector tilt }\left({ }^{\circ}\right) \\ \varepsilon & \text { Emissivity } \\ \dot{\mathrm{m}} & \text { Mass flow rate }(\mathrm{kg} / \mathrm{s}) \\ \eta_{1} & \text { Instantaneous efficiency } \\ \rho & \text { Density }\left(\mathrm{kg} / \mathrm{m}^{3}\right) \\ \tau & \text { Cover transmittance } \\ \sigma & \text { Stefan Boltzmann constant }\left(\mathrm{W} / \mathrm{m}^{2} \mathrm{~K}^{4}\right) \\ \mu & \text { Dynamic viscosity }(\mathrm{kg} / \mathrm{m} \mathrm{s})\end{array}$




\section{Subscripts:}

$\begin{array}{ll}\text { Used in emissivity calculations and radiation/convection heat transfer coefficients } \\ 1 & \text { Inner surface of collector cover } \\ 2 & \text { Absorber plate } \\ 3 & \text { Inner surface of back insulation } \\ \text { i } & \text { Inlet } \\ \text { o } & \text { Outlet }\end{array}$

\section{Glossary}

EPS

Expanded polystyrene

MVHR Mechanical ventilation with heat recovery

PIR Passive infrared sensor

TIM Translucent insulation material

TST Total solar transmittance

\subsection{Introduction}

The performance of our existing building stock must improve significantly if the UK is to meet the target of an $80 \%$ reduction in $\mathrm{CO}_{2}$ emissions by 2050, against the 1990 baseline [1]. For instance, housing in the UK accounts for $27 \%$ of $\mathrm{CO}_{2}$ emissions and more than $80 \%$ of the houses we will be living in by 2050 have already been built [2,3]. A range of promising new technologies are available, such as high performance translucent insulation in solar walls and solar collectors, as well as phase change materials for thermal energy storage. There is scope to retrofit these into existing buildings to make deep cuts in $\mathrm{CO}_{2}$ emissions, but their effective implementation is no trivial task $[3,4]$. Solutions must account for the variety of functions, composition, size, quality, age and social value of the existing building stock, as well as the different needs, expectations and budgets of owners and occupiers.

The aim of this study is to develop and test a new retrofit technology to demonstrate its potential energy savings and payback period. In-situ testing takes place in a dwelling, recently refurbished as part of the Technology Strategy Board's 'Retrofit for the Future' competition. The house is a three-storey 1960s pre-cast concrete end terrace, in South-East London, UK, with a large south facing wall, ideal to test new solar energy technologies. In its un-refurbished state, the hard-to-treat property suffered from moisture-related problems such as condensation, rising damp and mould growth made worse by insufficient supply of heating. Through refurbishment works, the property has been transformed following Passivhaus principles, from a four to a six bedroom house, super-insulated with external cladding (U-value $0.1 \mathrm{~W} / \mathrm{m}^{2} \mathrm{~K}$ ), triple glazing (U-value $0.8 \mathrm{~W} / \mathrm{m}^{2} \mathrm{~K}, \mathrm{G}$-value 0.5$)$ and high levels of air tightness $\left(3.5 \mathrm{~m}^{3} / \mathrm{m}^{2} . \mathrm{h}\right.$ (a) $50 \mathrm{~Pa}$ ). Fresh air is provided by mechanical ventilation with heat recovery (MVHR). Photovoltaic panels and vacuum tube collectors provide renewable electricity and water heating.

The focus of this paper is an innovative flat plate collector incorporated into the $2^{\text {nd }}$ floor of the external insulation on the south facade. The $6 \times 0.9$ metre prototype is designed to provide a free source of heating to the property by elevating the temperature of the extract air used to indirectly pre-heat the supply air for the MVHR. Basic components are (i) a cover, transparent to solar irradiance whilst reducing convection and radiation losses (ii) a black perforated solar absorbing sheet inside a cavity, (iii) back insulation to reduce conduction losses, and (iv), insulated ducts to transfer the air into the house. A novel feature of this prototype is its highly insulated translucent cover, consisting of a multi-wall polycarbonate panel filled with high 
performance granules of 'aerogel' insulation. This cover is predicted to reduce heat losses significantly through the collector compared to traditional glazed systems, whilst allowing sufficient solar transmission for heat collection.

\subsection{Background}

Since the late 1970s, considerable research has been undertaken to increase awareness of transparent insulation materials and demonstrate their enhanced performance over opaque and glazed elements applied to solar renovation projects $[5,6,7]$. When retrofitted to the outside of a south facing wall, as a Trombe wall, a transparent insulation material (TIM) with an air gap behind can be used to capture solar energy that can be used straight away by venting the warm air inside, or later, by allowing the heat to conduct passively through the wall. Athienitis and Ramadan [8] and Suehrcke et al. [9] demonstrate that in this application, TIMs such as glass or plastic honeycombs and flat or corrugated polycarbonate sheets can provide significant energy savings when retrofitted to residential and commercial walls. Dolley et al. [10] used a test cell to monitor the thermal performance of a polycarbonate honeycomb TIM system retrofitted to a southern wall. Extrapolating the results, for every $\mathrm{m}^{2}$ of TIM installed, the annual space heating requirement would reduce by $150 \mathrm{kWh}$ /year in a typical pre-1930s UK solid walled dwelling, or $40 \mathrm{kWh} /$ year in a super insulated home [10]. In a comparative study of six houses in France, Peuportier and Michel [11] found that honeycomb TIMs can increase the efficiency of conventional solar air collectors and Trombe walls by $25 \%$ and $50 \%$ respectively.

According to Kaushika and Sumathy [12] and Wong et al. [13] the most well documented application of TIM is in flat plate collectors for solar air or solar water heating. According to Hastings and Mørck [14], when integrated into the roof or façade of a dwelling, a solar air heater is ideal for pre-heating the ambient or return air in a mechanically ventilated dwelling. Rommel and Wagner [15] demonstrated how flat plate solar air collectors containing 50$100 \mathrm{~mm}$ polycarbonate honeycomb layers function well at lower temperature applications between $40-80^{\circ} \mathrm{C}$. Higher working temperatures of up to $260^{\circ} \mathrm{C}$ can be achieved using glass capillaries, whereas plastic covers are susceptible to melting at temperatures above $120 \circ \mathrm{C}[15]$. Schmidt et al. [16] and Kaushika and Reddy [17] both constructed small scale solar water heaters containing TIM covers in place of conventional glazing. Solar conversion efficiencies up to $63 \%$ and storage tank temperatures of $50-60{ }^{\circ} \mathrm{C}$ were attained, indicating that these systems would be an effective pre-heater. Authors commented that the TIM was found to minimise the risk of freezing whilst also obtaining solar fractions that outperformed some conventional domestic hot water systems.

A main advantage of using TIM instead of single or multiple glazed covers is the weight reduction, which can play an important factor in retrofit applications. For example, Okalux Kapipane [18], a transparent plastic honeycomb has a density of $30 \mathrm{~kg} / \mathrm{m}^{3}$, compared to glass at $2500 \mathrm{~kg} / \mathrm{m}^{3}$. Even at $40 \mathrm{~mm}$ thick, this product is 12.5 times lighter than glass weighing 0.6 $\mathrm{kg} / \mathrm{m}^{2}$, compared to $7.5 \mathrm{~kg} / \mathrm{m}^{2}$ for a $3 \mathrm{~mm}$ thick glass pane. Despite such benefits, significant implementation of outdoor solar energy systems incorporating TIM has been slow. Platzer and Goetzberger [19] estimated that over $15,000 \mathrm{~m}^{2}$ of TIM had been installed by the mid 1990s across 85 buildings throughout Germany, Austria and Switzerland, compared to just $1,000 \mathrm{~m}^{2}$ at the start of the decade. According to the authors, this indicated that the market situation was promising, but not satisfactory. Some of the key barriers include a lack of product development guides, imperfections in honeycomb or capillary TIMs, the low working temperatures of plastics and the potential for overheating when too much solar radiation is absorbed $[13,19]$. Further to this, the high investment cost of TIM, shading devices and control measures has presented barriers to widespread implementation [13,19]. Conversely, Wong et al. [13] claim that with improved design guidance combined with more information on the capital cost and 
payback periods of TIM in use, there will be increasing evidence to outweigh the barriers currently hindering market growth, especially as fuel prices increase in future, reducing pay back periods.

In a previous study containing a full review of transparent insulation materials applied to glazing, the corresponding author measured the in-situ U-value and light transmittance of a $10 \mathrm{~mm}$ thick translucent polycarbonate panel filled with high performance granular 'aerogel' insulation, retrofitted over an existing single glazed window [20]. Aerogel is a unique class of nano-porous insulation that exhibit the lowest thermal conductivity of any solid, by suppressing heat transfer by conduction, convection and thermal infrared radiation, whilst being highly translucent to light and solar irradiance $[21,22,23]$. Applied to the inside face of a window, the prototype was found to reduce heat loss by $80 \%$, equivalent to triple glazing, without detrimental reductions in light transmission [20]. If developed into a new retrofit product such as translucent secondary glazing or sliding shutters, payback periods between 3.5-9.5 years were predicted if the products were consistently used over the heating season [20]. This is considerably less than new double glazing, which can have paybacks far exceeding their 20 year product life span (for example Shorrock et al. [24] predicted a capital cost of $£ 4,000$ $(€ 4,826)$ for double glazing in a typical 3-bedroom semi detached house, compared to just $£ 40 /$ year (€48) in annual energy savings). In a follow-up study, a streamlined life cycle assessment of silica aerogel was conducted to verify that the amount of energy and $\mathrm{CO}_{2}$ required to manufacture the material does not outweigh the respective in-use savings [25]. Parity was achieved in 0-2 years, indicating that silica aerogel can provide a measurable environmental benefit [25].

Aerogel is often cited as a promising material for translucent insulation applications $[26,27,28,29,30]$. Thermal conductivities as low as $0.004 \mathrm{~W} / \mathrm{m} \mathrm{K}$ have been obtained through manufacturing solid monolithic aerogel tiles, prepared and evacuated in research laboratories [31]. Conversely, mass produced granules available to the construction industry can achieve low thermal conductivities of $0.018 \mathrm{~W} / \mathrm{m} \mathrm{K}$ [32]. According to Rubin and Lampert [33], the high cost, long processing time and difficulty manufacturing uniform samples protected from tension and moisture are key barriers hindering progress of monolithic aerogel production. By comparison, granular aerogel is cheaper, more robust and easier to produce on a commercial scale. The largest manufacturer is Cabot Corporation who produces 10,000 tonnes/year of 1$5 \mathrm{~mm}$ translucent, hydrophobic aerogel granules, which are completely moisture and mildew resistant [34,35]. Companies such as Kalwall, Pilkington and Okalux are now using granular aerogel across a wide range of applications [34]. Commercial products include filled polycarbonate, glass or glass-reinforced polyester glazing units, skylights and structural building panels [30].

The concept of a Trombe wall incorporating a monolithic aerogel cover encapsulated within double-glazing was originally proposed by Fricke [36]. According to modelling by Caps and Fricke [37], a 15mm thick monolithic aerogel cover, sandwiched between double glazing, then exerted to vacuum, could achieve minimal solar heat losses compared to conventional TIM due to its high solar transmission of $50-60 \%$ and low U-value of $0.5 \mathrm{~W} / \mathrm{m}^{2} \mathrm{~K}$. Despite this, Caps and Fricke [37] concluded that conventional TIMs are technically simpler as the evacuated system would also require a durable vacuum-tight metal rim. By comparison, Svendsen [38] constructed a $1.4 \mathrm{~m}^{2}$ flat plate collector prototype for water heating, with measured efficiencies of $60-80 \%$ indicating that the prototype could generate up to $700 \mathrm{kWh} / \mathrm{m}^{2} /$ year, being twice as good as commercial flat plate collectors. Modelling by Nordgaard and Beckman [39] verified this, demonstrating that the reduction in solar transmittance compared to a single glass pane is 
more than compensated by the reduction in heat losses, achieving efficiencies of more than $60 \%$.

Our literature review indentified a lack of in-situ studies of solar walls and/or solar collectors incorporating granular aerogel. This paper seeks to contribute to this field, motivated by the lower cost and increased functionality of granular aerogel over monolithic aerogel, supported by its recent emergence within the construction sector. Ortjohann [40] predicted that superinsulating solar thermal collectors could be produced using granular aerogel sandwiched inside an evacuated collector design. The main benefit would be its low weight, ease of handling and ability to provide an efficient collector design without an optimised absorber technology. Conversely, the main disadvantage would be the difficulty in maintaining a long-life of the vacuum technology [40]. Countering this, the performance of granular aerogel without a vacuum has been investigated by Wittwer [41] and Reim et al. [42]. U-values of 1.1 to 1.3 $\mathrm{W} / \mathrm{m}^{2} \mathrm{~K}$ were measured for $20 \mathrm{~mm}$ thick glazed samples [41]. Subsequently, even lower Uvalues of $0.4 \mathrm{~W} / \mathrm{m}^{2} \mathrm{~K}$ were measured for $20 \mathrm{~mm}$ thick plastic panels filled with granular aerogel, sandwiched between two glass panes with krypton and argon gas fillings [42]. According to Reim et al. [42] without the glass panes (and gas fillings), the solar transmittance of their prototype was $65 \%$, indicating high potential for use in insulated solar walls, with $40 \%$ less heat losses than conventional glass solar collectors.

\subsection{Prototype description}

A schematic diagram of the 'aerogel solar collector' constructed for this study, together with an outline of the monitoring equipment and control strategy, is shown within Figure 1. A floor plan layout showing the location of the prototype, alongside the supply and extract ductwork in the mechanical ventilation system is shown in Figure 2. The prototype is a flat plate solar air heater incorporated into an MVHR running in continuous operation. Air extracted from the kitchen and bathrooms is fed into the solar collector cavity, where it is heated by incoming solar irradiance. This heat is then used to provide additional energy to indirectly heat the incoming fresh air supply to the property's living room and bedrooms. Automatic flow and bypass controls maintain comfortable living conditions all year round, with radiators providing top-up heating when necessary.

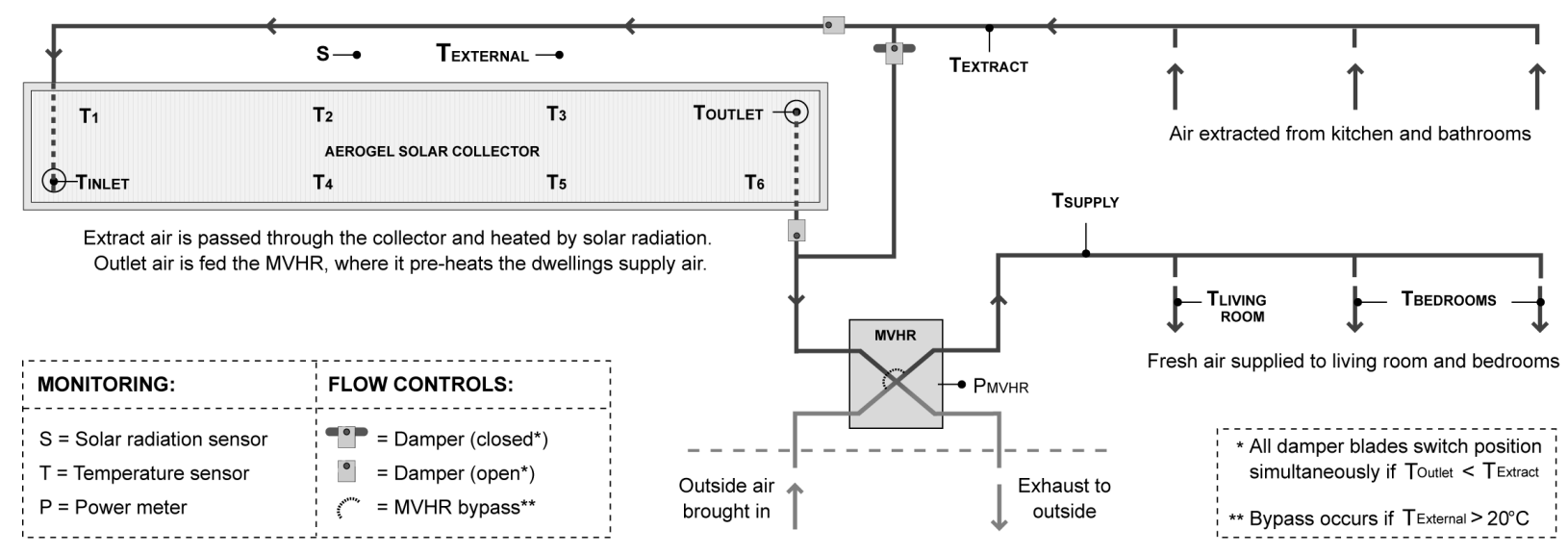

[Figure 1. Schematic of the aerogel solar collector and monitoring equipment] 

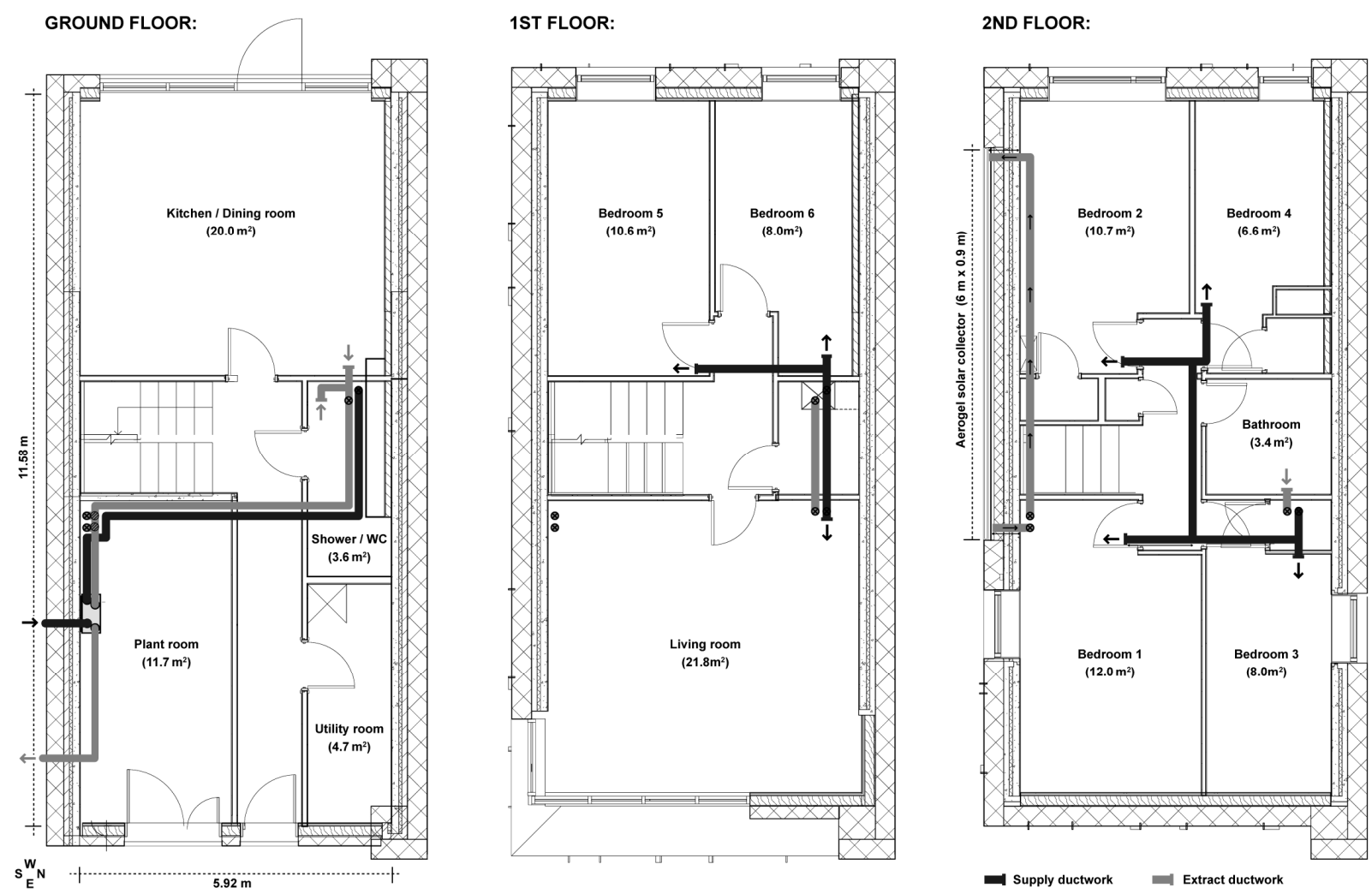

[Figure 2. Layout diagram of the house showing the aerogel solar collector and the location of supply and extract ductwork in the mechanical ventilation system]

Figure 3 contains a section through the inlet of the aerogel solar collector. The prototype consists of a $6 \times 0.9$ metre timber frame, painted black, at high level, retrofitted to the outside of the dwelling's existing south facing concrete façade. Fixed to the timber is an aluminium frame to support the cover system. Two $150 \mathrm{~mm}$ diameter holes were diamond cut through the external wall, in the bottom left and top right corners of the collector to facilitate the inlet and outlet respectively. $50 \mathrm{~mm}$ of mineral insulation was inserted in the back of the collector and around the perimeter of the timber frame to reduce back and edge heat losses. The absorber consists of three black powder coated perforated aluminium sheets fixed side-by-side spanning across the width of the collector. Each sheet is $1 \mathrm{~mm}$ thick and contains $4.7 \mathrm{~mm}$ diameter perforations at $8 \mathrm{~mm}$ pitches, creating a $40 \%$ open area. The sheet fitted on the inlet side of the collector has a pre-cut hole enabling the inlet ductwork to penetrate through so that incoming air passes over its surface. When fitted, there is an $80 \mathrm{~mm}$ cavity either side of the sheet.

The cover consists of twelve $40 \mathrm{~mm}$ thick multi-wall polycarbonate panels connected side-byside within the aluminium frame. This cover thickness was selected to enable the prototype to achieve an overall U-value below the Passivhaus target of $0.8 \mathrm{~W} / \mathrm{m}^{2} \mathrm{~K}$ for glazed openings [43]. This was important to the design team as the prototype was being integrated into the external cladding scheme, as opposed to being a stand-alone solar air collector mounted at roof level. This thickness was also preferred by the client over thinner covers, since it would enable a larger prototype to be constructed, more visible to the wider community, without increased risk of overheating inside the dwelling. Take note, in Section 5.1, thermal modelling demonstrates how the operational efficiency can be improved using thinner granular aerogel covers with higher solar transmittance, but worse U-values. Each of these polycarbonate covers can be manufactured to include additives for flame resistance and UV stabilisation, making them suitable for outdoor use and capable of withstanding temperatures up to $150^{\circ} \mathrm{C}$ without 
warping. They have Class 1 approval and a EuroClass (B-s 1, d0) fire rating, also when filled with aerogel [44].

\section{Solar Collector Section:}
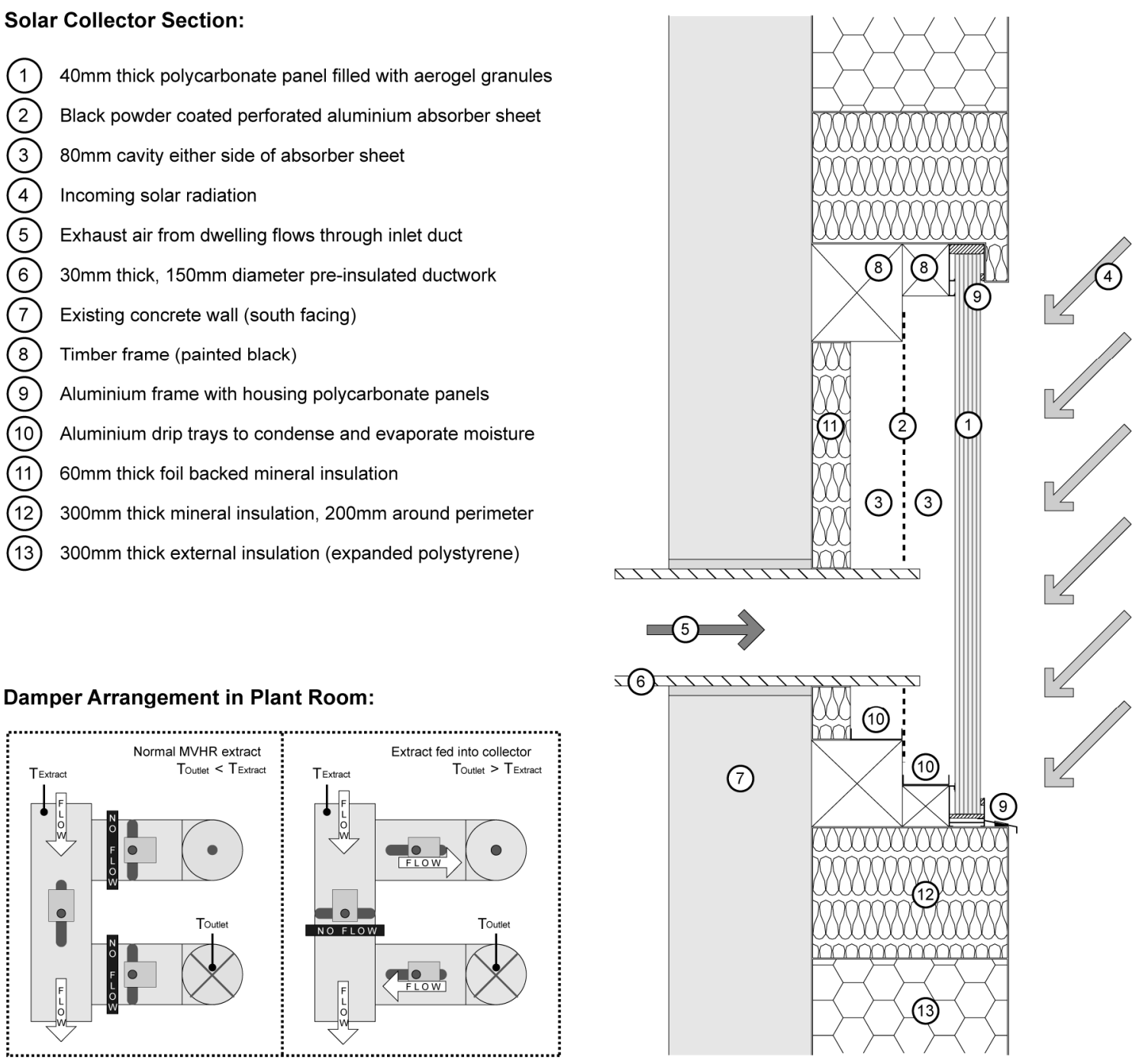

Damper Arrangement in Plant Room:

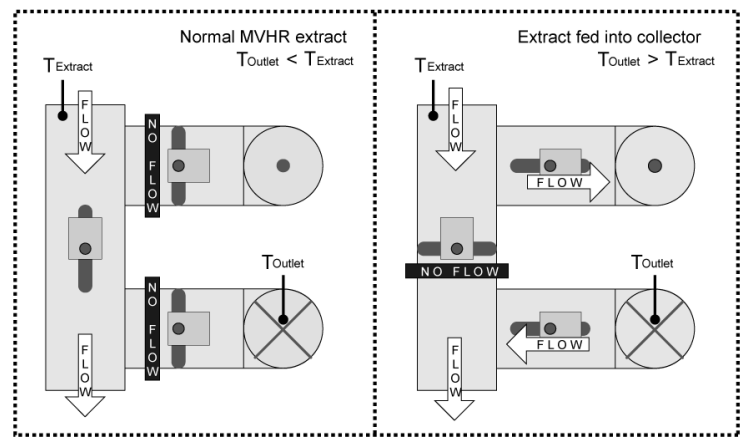

[Figure 3. Section through the inlet duct of the aerogel solar collector]

Prior to sealing the collector, eight temperature/humidity sensors with wireless radio transmitters were fixed to the perforated absorber sheet at high and low level to monitor the profile across the collector. Each sensor head is located behind the absorber sheet and contains a plastic shield to protect against direct solar irradiance. Sensors by the inlet and outlet ducts contain small caps allowing for protection against direct solar irradiance without disrupting airflow. All transmitters were fixed to the front of the absorber sheet to obtain the clearest signal down to a data hub in the plant room. Four additional temperature/humidity sensors were installed in the supply and extract ductwork for the MVHR, as well as in the living room and a north facing bedroom (shown as Bedroom 3 in Figure 2). A pyranometer mounted horizontally on the edge of the roof was used to measure the intensity of solar irradiance hitting the solar wall. A power meter on the MVHR measures the electricity consumption of the fans. All sensors provide 5-minute pulsed outputs.

Directing air to and from the solar collector are spans of $150 \mathrm{~mm}$ diameter pre-insulated ducts. Warm air from the collector outlet runs vertically down to a plant room on the ground floor. Inside the plant room is an arrangement of three dampers (shown in Figure 1), to direct air flow. These dampers operate simultaneously based on a changeover relay provided by a 
temperature differential electronic thermostat, supplied by Titan Products Ltd. This control unit is wired to two thermistors located in the solar collector outlet and exhaust air ductwork. Its changeover relay to direct air into the collector occurs when the outlet temperature is $5{ }^{\circ} \mathrm{C}$ greater than the exhaust temperature. The MVHR is the MRXBOX95B-WH1 with optional summer bypass, supplied from Nuaire. According to its specification, the unit recovers heat at $90 \%$ efficiency when operating in a dwelling with a kitchen and 3 additional wet rooms. The unit's summer bypass function (independent of the three control dampers) activates when the outside air temperature exceeds $20^{\circ} \mathrm{C}$.

\subsection{Calculation methodology}

Duffie and Beckman [45] provide one of the most comprehensive and widely cited resources for predicting the performance of solar energy technologies. With the exception of the overall heat loss coefficient $\left(\mathrm{U}_{\mathrm{L}}\right)$ and collector efficiency factor (F') equations derived by Parker [46], this reference provides the foundation for the following methodology used to predict the performance of the aerogel solar collector.

\subsection{Energy Balance Equation}

The steady state thermal performance of a flat-plate collector can be calculated from Equation (1), taking account of thermal and optical losses to determine the distribution of incident solar irradiance into useful energy gain $\left(\mathrm{Q}_{\mathrm{U}}\right)$.

$Q_{U}=A_{C} F_{R}\left[S(\tau \alpha)-U_{L}\left(T_{i}-T_{a}\right)\right]$

$A_{C}$ is the aperture area of the collector. $F_{R}$, refers to a plate efficiency or "heat removal factor". $\mathrm{S}$ is the total solar irradiance on the collector surface. $\tau$ is the transmittance of the cover. $\alpha$ is the absorptance of the absorber plate. $U_{L}$ is the overall heat loss coefficient of the collector. $T_{i}$ is the inlet fluid temperature. $T_{a}$ is the ambient air temperature outside.

\subsection{Collector Heat Losses}

The overall heat loss coefficient $\left(\mathrm{U}_{\mathrm{L}}\right)$ depends upon heat losses through the front and back of the collector, convection and radiation exchanges inside the cavity and heat losses due to wind. Figure 4 illustrates these parameters within a one-dimensional section of the aerogel solar collector. $h_{w}$ is the wind heat transfer coefficient, $h_{r}$ and $h_{c}$ are radiation and convection coefficients respectively, where the subscripts 1,2 and 3 correspond to the inner surface of the collector, the absorber plate, and the inner surface of the back insulation, respectively. $U_{\text {Front }}$ and $\mathrm{U}_{\mathrm{Back}}$ are the thermal transmittance through the respective layers.

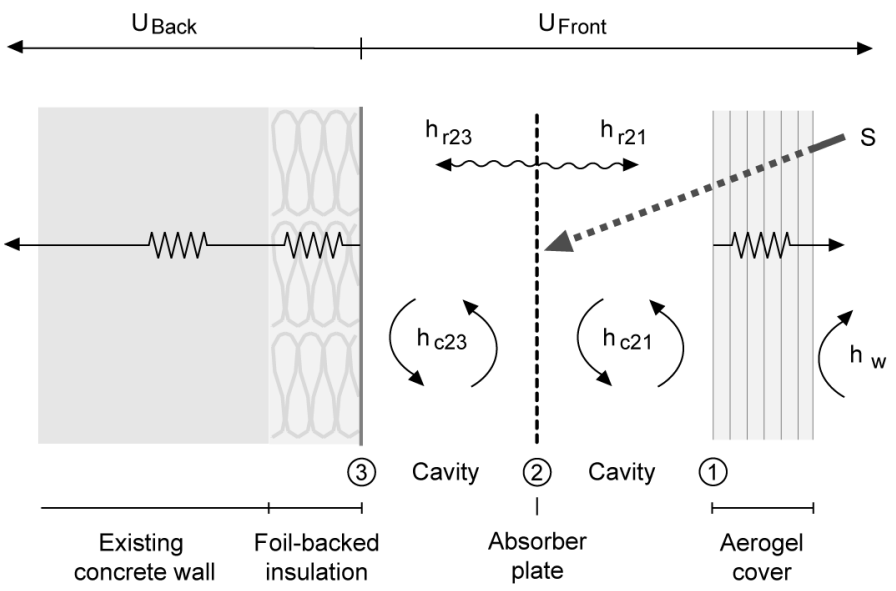

[Figure 4. Energy balance through solar collector] 
Duffie and Beckman [45] derive the loss coefficients for a variety of solar air collector layouts. However, the literature does not cover solar air collectors with airflow on both sides of the absorber sheet. Addressing this issue, Parker [46] determined that the overall heat loss coefficient for this arrangement can be calculated using Equation (2).

$$
\begin{aligned}
U_{L}= & \left\{4 h_{c 21} h_{c 23} U_{\text {Back }} U_{\text {Front }}+2 h_{r 21}\left[( h _ { c 2 1 } + h _ { c 2 3 } ) \left(h_{r 23} U_{\text {Front }}+U_{\text {Back }}\right.\right.\right. \\
& \left.\left.\left.U_{\text {Front }}+h_{r 23} U_{\text {Back }}\right)\right\}+h_{c 21} h_{c 23} U_{\text {Front }}\right]+2 h_{r 23} U_{\text {Back }}\left[h_{c 21} h_{c 23}\right. \\
& \left.+h_{c 21} U_{\text {Front }}+h_{c 23} U_{\text {Front }}\right]+h_{c 21} U_{\text {Front }}\left[h_{c 21}\left(2 h_{r 23}+h_{r 21}\right)\right. \\
& \left.+h_{r 23} Q+h_{c 21} U_{\text {Back }}\left[h_{c 21}\left(h_{r 23}+2 h_{c 23}\right)+h_{r 21} Q\right]\right\} / D
\end{aligned}
$$

Where:

$$
\begin{aligned}
D= & \left\{2 h_{c 21} h_{c 23} P+2 h_{c 23} U_{\text {Back }} U_{\text {Front }}+h_{r 21}\left[Q\left(h_{c 21}+h_{r 23}+U_{\text {Back }}\right)\right.\right. \\
& \left.\left.+h_{c 21} h_{r 23}\right]+h_{r 23} Q\left(h_{c 21}+U_{\text {Front }}\right)\right\} \\
P= & h_{c 21}+U_{\text {Back }}+U_{\text {Front }} \\
Q= & h_{c 21}+2 h_{c 23}
\end{aligned}
$$

\subsection{Radiation Coefficients}

The radiation heat transfer coefficients between the absorber plate and the collector $\left(\mathrm{h}_{\mathrm{r} 21}\right)$ and the absorber plate to the back insulation $\left(\mathrm{h}_{\mathrm{r} 23}\right)$ can be found using Equations (3) and (4) respectively.

$$
\begin{aligned}
& \mathrm{h}_{\mathrm{r} 21}=\frac{4 \sigma \mathrm{T}_{\mathrm{fm}}{ }^{3}}{\left(1 / \varepsilon_{1}\right)+\left(1 / \varepsilon_{2}\right)-1} \\
& \mathrm{~h}_{\mathrm{r} 23}=\frac{4 \sigma \mathrm{T}_{\mathrm{fm}}{ }^{3}}{\left(1 / \varepsilon_{2}\right)+\left(1 / \varepsilon_{3}\right)-1}
\end{aligned}
$$

Here, $\varepsilon$ is the surface emissivity and $\mathrm{T}_{\mathrm{fm}}$ is the mean fluid temperature, expressed in Kelvin. $\sigma$ is the Stefan Boltzmann constant. Note that $\mathrm{T}_{\mathrm{fm}}$, the mean fluid temperature, must be estimated at this stage, but can be corrected later using an iterative calculation [45]

\subsection{Convection Coefficients}

The convection heat transfer coefficients can be calculated using Equation (5).

$h_{c}=N u\left(k / D_{h}\right)$

$\mathrm{k}$ is the thermal conductivity of air at the estimated mean fluid temperature. $\mathrm{D}_{\mathrm{h}}$ is the hydraulic diameter of the air gap (two times the thickness). Nu refers to the Nusselt number, dependant on whether the flow regime is turbulent or laminar based on the Reynolds number, found using Equation (6).

$$
R e=\frac{2 \dot{m}}{H^{\prime} \mu}
$$


$\mu$ is the dynamic viscosity. $\dot{m}$ is the mass flow rate. $H^{\prime}$ is the height of the cavity. When $\operatorname{Re}<2300$ the fluid is laminar and Equation (7) should be used to calculate $\mathrm{Nu}$, whereas if $\operatorname{Re}>2300$, then the fluid should be treated as turbulent and Equation (8) is used.

$$
\begin{aligned}
\mathrm{Nu}_{\text {lamin ar }} & =4.9+\left[\frac{0.0606\left(\operatorname{Re} \operatorname{Pr} D_{\mathrm{h}} / H^{\prime}\right)^{1.2}}{1+0.909\left(\operatorname{Re} \operatorname{Pr} D_{\mathrm{h}} / H^{\prime}\right)^{0.7} \operatorname{Pr}^{0.17}}\right] \\
\mathrm{Nu}_{\text {turbulent }} & =0.0158 \mathrm{Re}^{0.8}
\end{aligned}
$$

Pr is the Prandtl number, calculated from Equation (9), where $C_{p}$ is the specific heat capacity of the fluid (air) inside the collector.

$\operatorname{Pr}=\frac{\mu \mathrm{Cp}}{\mathrm{k}}$

\subsection{Front Losses}

Front heat losses through a single cover $\left(\mathrm{U}_{\text {Front }}\right)$ can be calculated using Equation (10).

$$
\begin{aligned}
U_{\text {Front }} & =\left[\frac{C}{T_{p m}}\left(\frac{T_{p m}-T_{a}}{1+f}\right)^{e}+\frac{1}{h_{w}}\right]^{-1} \\
& +\frac{\sigma\left(T_{p m}+T_{a}\right)\left(T_{p m}{ }^{2}+T_{a}{ }^{2}\right)}{\left(\varepsilon_{2}+0.00591 h_{w}\right)^{-1}+\left(\frac{1+f+0.133 \varepsilon_{2}}{\varepsilon_{1}}\right)-1}
\end{aligned}
$$

Where:

$$
\begin{aligned}
& f=1.07866\left(1+0.089 h_{w}-0.1166 h_{w} \varepsilon_{p}\right) \\
& C=520\left(1-0.00005 \beta^{2}\right) \\
& e=0.430\left(1-100 / T_{p m}\right)
\end{aligned}
$$

$\varepsilon_{1}$ and $\varepsilon_{2}$ are the emissivity of the cover and absorber plate respectively. $\mathrm{T}_{\mathrm{a}}$ and $\mathrm{T}_{\mathrm{pm}}$ correspond to ambient temperature and mean plate temperature, respectively, expressed in Kelvin. $T_{\mathrm{pm}}$ must be estimated at this stage, but will be corrected later using an iterative calculation. $h_{w}$ is the wind heat transfer coefficient. $\beta$ is the collector tilt in degrees.

\subsection{Wind Coefficient}

The wind heat loss coefficient, $\mathrm{h}_{\mathrm{w}}$, accounting for free and forced convection, can be calculated using Equation (11).

$$
\mathrm{h}_{\mathrm{w}}=\max \left(5, \frac{8.6 \mathrm{v}_{\mathrm{w}}{ }^{0.6}}{\mathrm{~L}^{0.4}}\right)
$$

Here, $\mathrm{v}_{\mathrm{w}}$ is the wind velocity and $\mathrm{L}$ is the cube root of the dwelling volume. According to Duffie and Beckman [45], a minimum value of $5 \mathrm{~W} / \mathrm{m}^{2} \mathrm{~K}$ occurs in vertical solar collectors under still conditions. 


\subsection{Back Losses}

Thermal losses through the back of the collector are calculated using Equation (12).

$\mathrm{U}_{\text {Back }}=\frac{1}{\sum_{i-1}^{\mathrm{i}=\mathrm{n}} \mathrm{R}_{\mathrm{i}}}$

Here, $\sum_{i-1}^{i=n} R_{i}$ is the sum of the thermal resistances of the insulation layers. For the aerogel solar collector, these layers consist of the back insulation inside the collector, as well as the thermal resistance and internal surface resistance of the existing wall.

\subsection{Heat Removal Factor}

The heat removal factor $\left(\mathrm{F}_{\mathrm{R}}\right)$ is a ratio between the actual useful energy gain of the collector to the maximum possible useful energy gain, obtained by setting the mean plate temperature to the inlet temperature so that heat losses are minimised. $F_{R}$ is the product of two design constants: the collector efficiency factor ( $\left.F^{\prime}\right)$ and a collector flow factor $\left(F^{\prime \prime}\right)$, as shown in Equation (13).

$F_{R}=F^{\prime} F^{\prime \prime}$

\subsection{Collector Efficiency Factor}

According to Parker [46], for solar air collectors with flow on both sides of the absorber plate, the collector efficiency factor ( $F$ ') can be calculated using Equation (14), where the values of $\mathrm{D}, \mathrm{P}$ (and Q) are given in Equation (2).

$$
\begin{aligned}
F^{\prime} & =D /\left\{2 h_{c 21} h_{c 23} P+2 h_{c 23} U_{\text {Back }} U_{\text {Front }}+h_{r 21}\left[\left(h_{c 21}+h_{r 23}\right)\left(P+2 h_{c 23}\right)\right.\right. \\
& \left.+U_{\text {Back }}\left(2 h_{c 23}+U_{\text {Front }}\right)+h_{c 21} h_{r 23}\right]+h_{r 23}\left[h_{c 21}\left(P+2 h_{c 23}\right)\right. \\
& \left.\left.+2 h_{c 23} U_{\text {Front }}+U_{\text {Back }} U_{\text {Front }}\right]\right\}
\end{aligned}
$$

\subsection{Collector Flow Factor}

The collector flow factor ( $F$ ' ') can be calculated from Equation (15). Here $\frac{\dot{m} C p}{A_{C} U_{L} F}$ can be defined as the 'dimensionless collector mass flow rate'.

$F^{\prime \prime}=\frac{\dot{m} C p}{A_{C} U_{L} F^{\prime}}\left[1-\exp \left(-\frac{A_{C} U_{L} F^{\prime}}{\dot{m} C p}\right)\right]$

\subsection{Mean Fluid Temperature}

At this stage, it is possible to calculate $Q_{u}$, using Equation (1). In turn, the mean fluid temperature can be calculated using Equation (16):

$T_{f m}=T_{i}+\frac{Q_{U} / A_{C}}{F_{R} U_{L}}\left(1-F^{\prime \prime}\right)$

In Equations (3) and (4), $\mathrm{T}_{\mathrm{fm}}$ was estimated. As such, the recalculated value should be fed back into the original equations. According to Duffie and Beckman [45], typically 2-3 iterations provide sufficiently accurate values. Alternatively, computer packages can automate iteration loops updating values dependant on fluid properties such as density, specific heat capacity, thermal conductivity, dynamic viscosity and the Prandtl number. 


\subsection{Mean Plate Temperature}

Similarly, the mean plate temperature can be calculated using Equation (17). Again, the recalculated value should be fed back into the original equations, using an iterative process.

$$
T_{p m}=T_{i}+\frac{Q_{U} / A_{C}}{F_{R} U_{L}}\left(1-F_{R}\right)
$$

\subsection{Outlet Temperature}

The basic method of measuring collector performance is to expose it to solar irradiance and measure the inlet and outlet temperatures and the fluid flow rate. The useful gain can then be calculated using Equation (18):

$$
Q_{U}=\dot{m} C p\left(T_{o}-T_{i}\right)
$$

Rearranging this equation in terms of the outlet temperature $\left(T_{0}\right)$ gives Equation (19):

$$
\mathrm{T}_{\mathrm{O}}=\mathrm{T}_{\mathrm{i}}+\frac{\mathrm{Q}_{U}}{\dot{\mathrm{m} C p}}
$$

\subsection{Ductwork Heat Losses}

Heat losses in the ductwork leaving a solar collector can be significant [45]. The temperature $\operatorname{drop}\left(\Delta \mathrm{T}_{\mathrm{o}}\right)$ from ductwork can be calculated using Equation (20):

$$
\Delta \mathrm{T}_{\mathrm{o}}=\frac{\mathrm{U}_{\mathrm{d}} \mathrm{A}_{\mathrm{d}}\left(\mathrm{T}_{\mathrm{o}} \mathrm{T}_{\text {inside }}\right)}{\dot{\mathrm{m} C p}}
$$

$\mathrm{T}_{\text {inside }}$ is the internal temperature, assuming ductwork runs internally through the building. $A_{d}$ is the exposed area of the ductwork where thermal losses occur. $U_{d}$ is the heat loss coefficient of the ducting.

\subsection{Instantaneous efficiency of collector}

Instantaneous efficiency can be calculated using Equation (21):

$$
\eta_{1}=\frac{Q_{U}}{A_{C} S}=F_{R}(\tau \alpha)-\frac{F_{R} U_{L}\left(T_{i}-T_{a}\right)}{S}
$$

\subsection{MVHR supply temperature}

The resultant supply air temperature leaving an MVHR, following indirect heat exchange with the exhaust air can be calculated using Equation (22), where $\eta_{M V H R}$ is the efficiency of the MVHR heat exchanger and $T_{o}$ is the outlet temperature of the collector, adjusted to account for ductwork heat losses:

$$
T_{s}=T_{a}+\left[\eta_{M V H R}\left(T_{o}-T_{a}\right)\right]
$$

\subsection{Steady state model}

Table 1 displays the interface of a steady state model created to characterise the aerogel solar collector. Key inputs include the collector make-up and dimensions, the weather conditions and the inlet fluid properties. Key outputs include the overall efficiency, collector efficiency factor, overall heat loss parameter and heat removal factor, as well as the outlet temperature and useful energy before/after passing through the ductwork leading to the MVHR. The model includes an iteration loop to correct initial estimations for the mean plate temperature and mean fluid 
temperature. The model also calculates resultant supply air temperature leaving the MVHR based on the efficiency of the heat exchanger. Values can be compared to the baseline supply temperature without the solar collector.

\begin{tabular}{|c|c|c|c|c|c|c|c|c|c|c|c|c|}
\hline \multicolumn{13}{|c|}{ CHARACTERISE CONSTRUCTION LAYERS } \\
\hline & & & & $\begin{array}{c}\text { Aerogel } \\
\text { panel }\end{array}$ & $\begin{array}{l}\text { Air gap } \\
\text { (front) }\end{array}$ & $\begin{array}{c}\text { Black } \\
\text { aluminium }\end{array}$ & $\begin{array}{l}\text { Air gap } \\
\text { (back) }\end{array}$ & $\begin{array}{c}\text { Foil-backed } \\
\text { insulation }\end{array}$ & $\begin{array}{c}\text { Concrete } \\
\text { inner-leaf }\end{array}$ & $\begin{array}{c}\text { EPS } \\
\text { insulation }\end{array}$ & $\begin{array}{c}\text { Concrete } \\
\text { outer-leaf }\end{array}$ & $\begin{array}{c}\text { Inner } \\
\text { surface }\end{array}$ \\
\hline 1 & Thickness & $x$ & $\mathrm{~m}$ & 0.040 & 0.080 & 0.001 & 0.080 & 0.060 & 0.080 & 0.035 & 0.105 & - \\
\hline 2 & Conductivity & k & $\mathrm{W} / \mathrm{m} \mathrm{K}$ & 0.022 & - & 250 & - & 0.035 & 1.701 & 0.040 & 1.701 & - \\
\hline 3 & Resistance & $\mathrm{R}$ & $\mathrm{m}^{2} / \mathrm{K} / \mathrm{W}$ & 1.85 & - & 0 & - & 1.71 & 0.05 & 0.88 & 0.06 & 0.13 \\
\hline 4 & U-value & $U$ & $\mathrm{~W} / \mathrm{m}^{2} \mathrm{~K}$ & 0.54 & - & 250000 & - & 0.58 & 21.26 & 1.14 & 16.20 & 7.69 \\
\hline 5 & Emissivity & $\varepsilon$ & - & 0.91 & - & 0.70 & - & 0.10 & - & - & - & - \\
\hline
\end{tabular}

\begin{tabular}{|llccc|}
\hline \multicolumn{5}{|c|}{ CHARACTERISE WEATHER } \\
\hline & & & & \\
& Ambient temperature & $\mathrm{Ta}_{\mathrm{a}}$ & ${ }^{\circ} \mathrm{C}$ & Input \\
7 & Incident radiation & $\mathrm{S}$ & $\mathrm{W} / \mathrm{m}^{2}$ & 500 \\
8 & Wind velocity & $\mathrm{v}_{\mathrm{w}}$ & $\mathrm{m} / \mathrm{s}$ & 5 \\
\hline
\end{tabular}

\begin{tabular}{|llccc|}
\hline \multicolumn{5}{|c|}{ CHARACTERISE FLAT PLATE COLLECTOR } \\
\hline 9 & Width & $\mathrm{W}$ & $\mathrm{m}$ & Input \\
& Height & $\mathrm{H}$ & $\mathrm{m}$ & 0.00 \\
11 & Tilt & $\mathrm{B}$ & ${ }^{\circ}$ & 90 \\
12 & Cover transmittance & $\mathrm{T}$ & - & 0.46 \\
13 & Plate absorptance & $\mathrm{a}$ & - & 0.54 \\
\hline 14 & Mean absorber temperature & $\mathrm{T}_{\mathrm{pm}}$ & ${ }^{\circ} \mathrm{C}$ & 34.61 \\
15 & Mean fluid temperature & $\mathrm{T}_{\mathrm{fm}}$ & ${ }^{\circ} \mathrm{C}$ & 34.18 \\
\hline
\end{tabular}

\begin{tabular}{|llccc|}
\hline \multicolumn{4}{|c|}{ CHARACTERISE HEAT TRANSFER FLUID } \\
\hline & & & & Input \\
\cline { 5 - 5 } 16 & Mass flow rate & $\dot{\mathrm{m}}$ & $\mathrm{kg} / \mathrm{s}$ & 0.043 \\
17 & Inlet air temperature & $\mathrm{T}_{\mathrm{i}}$ & ${ }^{\circ} \mathrm{C}$ & 23 \\
18 & Average cavity height & $\mathrm{H}^{\prime}$ & $\mathrm{m}$ & 0.687 \\
\hline 19 & Density & $\rho$ & $\mathrm{kg} / \mathrm{m}^{3}$ & 1.1655 \\
20 & Specific heat capacity & $\mathrm{C}_{\mathrm{p}}$ & $\mathrm{J} \mathrm{kg} \mathrm{K}$ & 1006.5 \\
21 & Thermal conductivity & $\mathrm{K}$ & $\mathrm{W} / \mathrm{m} \mathrm{K}$ & 0.02645 \\
22 & Dynamic viscosity & $\mu$ & $\mathrm{kg} / \mathrm{m} \mathrm{s}$ & $1.86 \mathrm{E}-05$ \\
23 & Prantl number & $\mathrm{Pr}$ & - & 0.705 \\
\hline
\end{tabular}

\begin{tabular}{|c|c|c|c|c|}
\hline \multicolumn{5}{|c|}{ CALCULATIONS } \\
\hline & & & & Output \\
\hline 31 & Stephan botlzman constant & $\sigma$ & - & 5.67E-08 \\
\hline 32 & Hydraulic diameter & $\mathrm{Dh}$ & $\mathrm{m}$ & 0.16 \\
\hline 33 & Reynolds number & $\operatorname{Re}$ & - & 6748 \\
\hline 34 & Flow regime? & & - & Turbulent \\
\hline 35 & Nusselt number & $\mathrm{Nu}$ & - & \\
\hline 36 & Laminar flow calculation & & - & $n / a$ \\
\hline 37 & Turbulent flow calculation & & - & 18.28 \\
\hline 38 & & Selection: & - & 18.28 \\
\hline 39 & Wind co-efficient & $h_{w}$ & $\mathrm{~W} / \mathrm{m}^{2} \mathrm{~K}$ & 10.16 \\
\hline 40 & Convection co-efficient & $\mathrm{h}_{\mathrm{c} 21}$ & $\mathrm{~W} / \mathrm{m}^{2} \mathrm{~K}$ & 3.02 \\
\hline 41 & Convection co-efficient & $\mathrm{h}_{\mathrm{c} 23}$ & $\mathrm{~W} / \mathrm{m}^{2} \mathrm{~K}$ & 3.02 \\
\hline 42 & Radiation co-efficient & $h_{r 21}$ & $\mathrm{~W} / \mathrm{m}^{2} \mathrm{~K}$ & 4.30 \\
\hline 43 & Radiation co-efficient & $h_{r 23}$ & $\mathrm{~W} / \mathrm{m}^{2} \mathrm{~K}$ & 0.65 \\
\hline 44 & Back losses & $\mathrm{U}_{\mathrm{b}}$ & $\mathrm{W} / \mathrm{m}^{2} \mathrm{~K}$ & 0.35 \\
\hline 45 & Front losses & $U_{f}$ & $\mathrm{~W} / \mathrm{m}^{2} \mathrm{~K}$ & 0.47 \\
\hline 46 & Overall losses & $\mathrm{U}_{\mathrm{L}}$ & $\mathrm{W} / \mathrm{m}^{2} \mathrm{~K}$ & 0.78 \\
\hline 47 & Collector efficiency factor & $F^{\prime}$ & - & 0.96 \\
\hline 48 & Capacitance rate & - & - & 10.62 \\
\hline 49 & Collector flow factor & $F^{\prime \prime}$ & - & 0.95 \\
\hline 50 & Heat removal factor & $F_{R}$ & - & 0.92 \\
\hline 51 & Area of outlet ducting & Ao & $\mathrm{m}^{2}$ & 4.71 \\
\hline 52 & Loss co-efficient of ducts & $\mathrm{U}_{\mathrm{d}}$ & $\mathrm{W} / \mathrm{m}^{2} \mathrm{~K}$ & 1.17 \\
\hline 53 & Temperature drop from ducts & $T_{d}$ & ${ }^{\circ} \mathrm{C}$ & 1.89 \\
\hline
\end{tabular}

\begin{tabular}{|llccc|}
\hline \multicolumn{5}{c|}{ CHARACTERISE DWELLING } \\
\hline & & & & \\
\cline { 4 - 5 } 24 & Total volume & $\mathrm{V}$ & $\mathrm{m}^{3}$ & 400 \\
25 & Internal temperature & $\mathrm{Ta}$ & ${ }^{\circ} \mathrm{C}$ & 21 \\
\hline
\end{tabular}

\begin{tabular}{|llccc|}
\hline \multicolumn{5}{|c|}{ CHARACTERISE OUTLET DUCTWORK } \\
\hline & & & \\
\cline { 3 - 4 } 26 & Duct diameter & $\mathrm{D}$ & $\mathrm{m}$ & Input \\
27 & Duct length & $\mathrm{L}$ & $\mathrm{m}$ & 10 \\
28 & Insulation thickness & $\Delta \mathrm{x}$ & $\mathrm{m}$ & 0.03 \\
29 & Insulation conductivity & $\mathrm{k}$ & $\mathrm{W} / \mathrm{m} \mathrm{K}$ & 0.035 \\
\hline
\end{tabular}

\begin{tabular}{|c|c|c|c|c|}
\hline \multicolumn{5}{|c|}{ CHARACTERISE MVHR } \\
\hline & & & & Input \\
\hline 30 & Heat exchange efficiency & $\eta_{\mathrm{MVHR}}$ & $\%$ & $90 \%$ \\
\hline
\end{tabular}

\begin{tabular}{|c|c|c|c|c|}
\hline \multicolumn{5}{|c|}{ PREDICTED PERFORMANCE } \\
\hline & & & & Output \\
\hline \multicolumn{5}{|c|}{ Solar collector performance } \\
\hline 54 & Useful energy & $\mathrm{Q}_{\mathrm{u}}$ & W & 555.90 \\
\hline & Outlet temperature & $T_{0}$ & ${ }^{\circ} \mathrm{C}$ & 35.84 \\
\hline & Mean plate temperature & $T_{\mathrm{pm}}$ & ${ }^{\circ} \mathrm{C}$ & 3461 \\
\hline 57 & Mean fluid temperature & $T_{\mathrm{fm}}$ & ${ }^{\circ} \mathrm{C}$ & 34.18 \\
\hline & Instantaneous efficiency & $\eta_{1}$ & $\%$ & 0.21 \\
\hline \multicolumn{5}{|c|}{ Effect of ductwork leaving collector } \\
\hline & Useful energy & $\mathrm{Q}_{\mathrm{u}}$ & W & 474.29 \\
\hline & Outlet temperature & $T_{0}$ & ${ }^{\circ} \mathrm{C}$ & 33.96 \\
\hline \multicolumn{5}{|c|}{ Supply temperature to house } \\
\hline & Basecase (no solar collector) & $\mathrm{T}_{\mathrm{s}}$ & ${ }^{\circ} \mathrm{C}$ & 21.45 \\
\hline & Supply temp with solar collector & $\mathrm{T}_{\mathrm{s}}$ & ${ }^{\circ} \mathrm{C}$ & 31.31 \\
\hline
\end{tabular}

[Table 1. Input and output parameters of the steady state model]

When characterising the collector, the model assumes heat flow through the cover and back is one-dimensional, and construction properties are independent of temperature. Edge losses and the effects of dust, dirt and moisture are not considered. The collector is assumed to be completely airtight. Air properties are dependant on the mean fluid temperature inside the collector. Perforations in the double sided absorber plate (exposed area of 40\%) are accounted for by reducing plate absorption to ( $\alpha$ x 0.6 ). The average wind velocity is taken as $5 \mathrm{~m} / \mathrm{s}$. To account for the thickness of the granular aerogel cover, its thermal resistance is added in series to the front heat loss coefficient. 


\subsection{Cover Efficiency Investigation}

To investigate the efficiency of different solar collector covers, Table 2 displays the predicted heat removal factor, overall heat loss parameter and collector efficiency factor, based upon the U-value and total solar transmittance (TST) of four multi-wall polycarbonate panels filled with granular aerogel at $10 \mathrm{~mm}, 16 \mathrm{~mm}, 25 \mathrm{~mm}$ and $40 \mathrm{~mm}$ thicknesses [47]. Values are benchmarked against properties of single glazing, double glazing and a double glazed cover encapsulating a $15 \mathrm{~mm}$ layer of high performance monolithic silica aerogel [48].

\begin{tabular}{|l|c|c|c|c|c|}
\hline Solar collector cover type & U-value & TST & FR & UL & F' \\
\hline Single glazing & 5.70 & 0.85 & 0.63 & 4.36 & 0.78 \\
Double glazing & 2.80 & 0.80 & 0.74 & 2.71 & 0.85 \\
$10 \mathrm{~mm}$ granular aerogel & 1.48 & 0.70 & 0.86 & 1.31 & 0.93 \\
$16 \mathrm{~mm}$ granular aerogel & 0.97 & 0.62 & 0.89 & 1.06 & 0.94 \\
25mm granular aerogel & 0.62 & 0.61 & 0.91 & 0.84 & 0.96 \\
$40 \mathrm{~mm}$ granular aerogel & 0.54 & 0.46 & 0.92 & 0.78 & 0.96 \\
$15 \mathrm{~mm}$ monolithic aerogel & 0.66 & 0.75 & 0.91 & 0.87 & 0.96 \\
\hline
\end{tabular}

[Table 2. Design parameters for different collector covers calculated from the U-value and total solar transmittance (TST)]

As shown, the single glazed cover has the highest solar transmittance at 0.85 , however, its Uvalue is also the highest at $5.7 \mathrm{~W} / \mathrm{m}^{2} \mathrm{~K}$. Conversely, the $40 \mathrm{~mm}$ granular aerogel cover has the lowest solar transmittance at 0.46 , but also the lowest $\mathrm{U}$-value at $0.54 \mathrm{~W} / \mathrm{m}^{2} \mathrm{~K}$. The monolithic aerogel cover retains good properties for both, with its high solar transmittance of 0.75 and low U-value of $0.66 \mathrm{~W} / \mathrm{m}^{2} \mathrm{~K}$. Regarding $\mathrm{U}_{\mathrm{L}}, \mathrm{F}_{\mathrm{R}}$ and $\mathrm{F}$ ', it is evident that the cover's U-value has a large influence on the overall collector losses $\mathrm{U}_{\mathrm{L}}$. Similarly, the collector efficiency factor and heat removal factor, representing the ability of the collector to retain heat, are strong functions of the cover's U-value. Conversely, TST has a less significant impact on $U_{L}, F_{R}$ and F'. It should be noted, however, that higher transmittance increases the mean plate and fluid temperatures, resulting in higher radiation and convection heat transfer coefficients, increasing the overall losses.

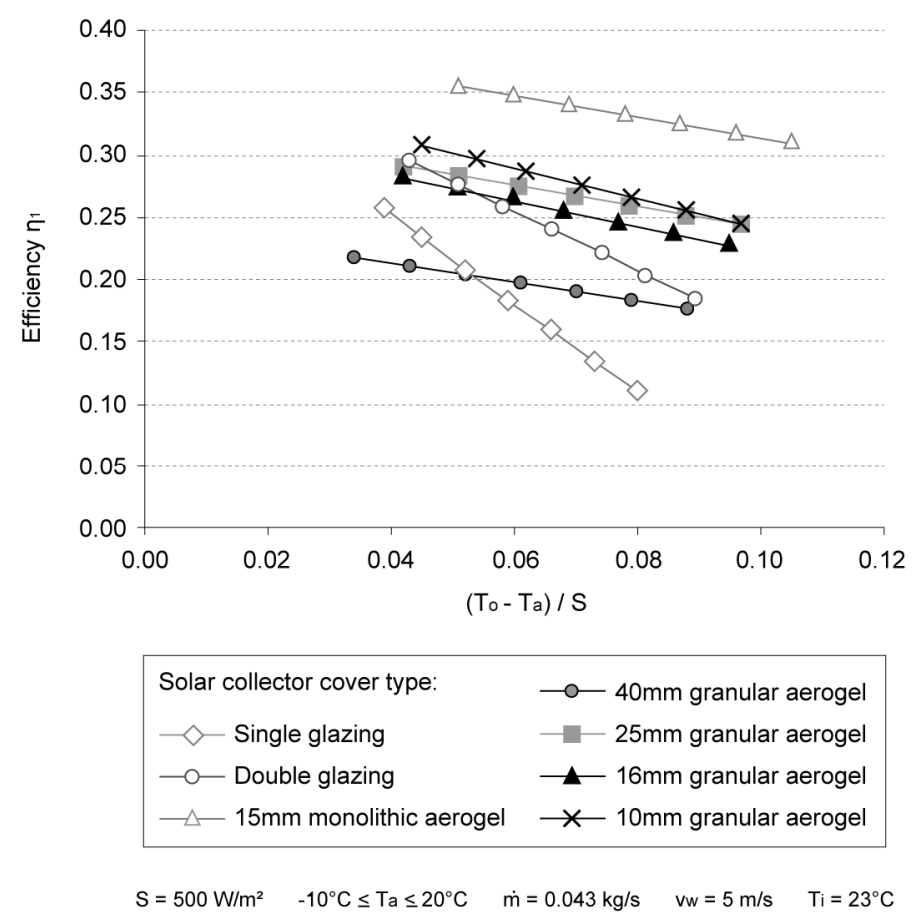

[Figure 5. Efficiency curves for different solar collector covers] 
Hastings and Mørck [14] state that efficiency curves for closed loop solar air collectors should be produced as a function of the outlet and ambient temperature in the form $\left(\mathrm{T}_{0}-\mathrm{T}_{\mathrm{a}}\right) / \mathrm{S}$. Figure 5 displays the overall efficiency of each collector cover, when incorporated into the $6 \times 0.9$ metre solar air collector designed for this study. Outlet temperatures and efficiencies are calculated for ambient temperatures ranging from $-10 \circ \mathrm{C}$ to $+20^{\circ} \mathrm{C}$. Solar irradiance and wind speed are $500 \mathrm{~W} / \mathrm{m}^{2}$ and $5 \mathrm{~m} / \mathrm{s}$ respectively. The inlet air temperature is taken as $23{ }^{\circ} \mathrm{C}$ with a mass flow rate of $0.043 \mathrm{~kg} / \mathrm{s}$ (based on an extract airflow rate of $37 \mathrm{~L} / \mathrm{s}$ for a house with one kitchen and three bathrooms).

According to the efficiency calculations, the solar collector containing monolithic aerogel operates at the highest efficiency, peaking at $36 \%$ when ambient temperature is set to $20{ }^{\circ} \mathrm{C}$. Alternatively, the $10 \mathrm{~mm}$ thick cover is the best performing granular aerogel system, with peak efficiencies of $31 \%$, followed by the $25 \mathrm{~mm}$ and $16 \mathrm{~mm}$ thickness covers at $29 \%$. The $40 \mathrm{~mm}$ cover performs less favourable with a peak efficiency of $22 \%$. Interestingly the single glazed cover provides a higher efficiency than this system, when ambient temperature is between 10$20{ }^{\circ} \mathrm{C}$. However, when ambient temperature drops below this value, the $40 \mathrm{~mm}$ cover provides a higher efficiency due to it improved heat retention properties, evident from the shallower gradient as seen on all of the aerogel collectors. Similarly, the double glazed collector has a higher efficiency than the $16 \mathrm{~mm}$ and $25 \mathrm{~mm}$ granular aerogel covers at ambient temperatures above $20^{\circ} \mathrm{C}$, but below this temperature its efficiency is lower.

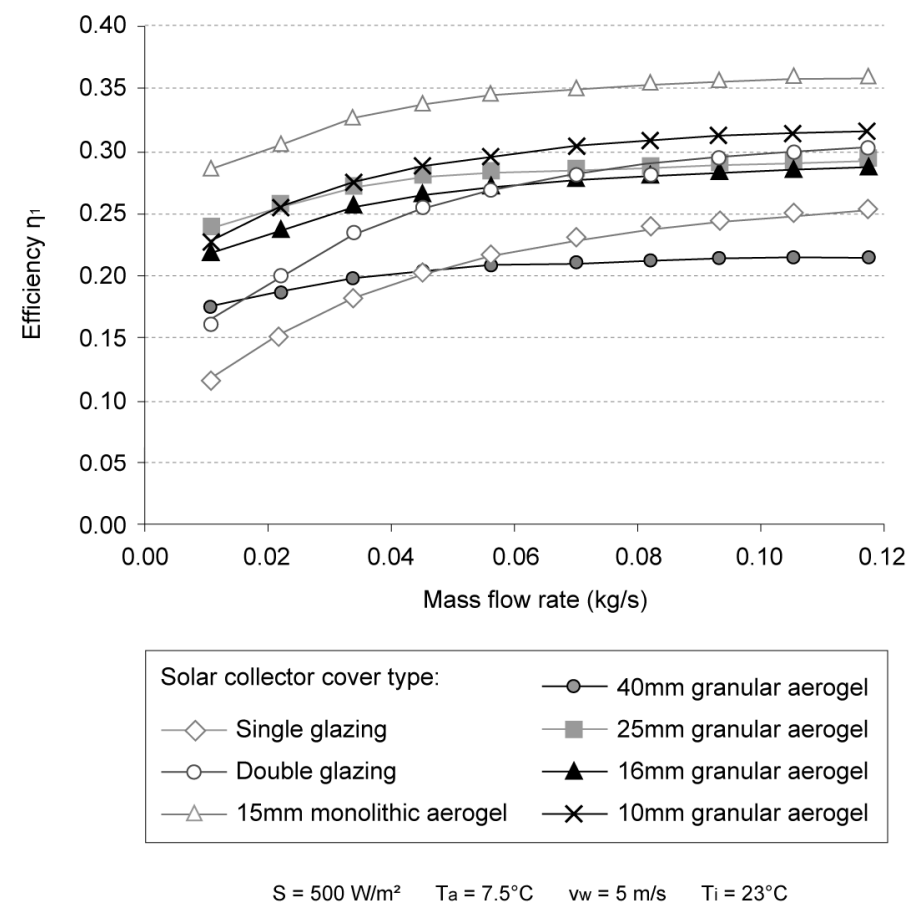

[Figure 6. Efficiency curves at different mass flow rates]

Figure 6 displays the predicted collector efficiencies at different mass flow rates. In each calculation, solar irradiance, wind speed and inlet temperatures are assumed to be $500 \mathrm{~W} / \mathrm{m}^{2}, 5$ $\mathrm{m} / \mathrm{s}$ and $23^{\circ} \mathrm{C}$ respectively. An ambient temperature of $7.5^{\circ} \mathrm{C}$ was selected to represent the average external temperature during October 1st - May 31st, the months where approximately $90 \%$ of the degree-days for London Thames Valley occur [49], calculated using hourly weather data from the CIBSE TRY London weather file [50]. As shown, higher efficiencies occur at higher mass flow rates due to the mean temperature of the collector being lower, resulting in less heat losses. Again, there are conditions when the single glazed collector outperforms the 
$40 \mathrm{~mm}$ granular aerogel system. In this instance, mass flow rates above $0.050 \mathrm{~kg} / \mathrm{s}$ result in the single glazed collector operating at a higher efficiency. Similarly, the double glazed collector operates at a higher efficiency than the $16 \mathrm{~mm}$ granular aerogel system at mass flow rates above $0.065 \mathrm{~kg} / \mathrm{s}$. By comparison, the $10 \mathrm{~mm}$ cover provides a higher efficiency than both glazed collectors. The $15 \mathrm{~mm}$ monolithic aerogel covers possess significantly higher operating efficiencies across all flow rates investigated.

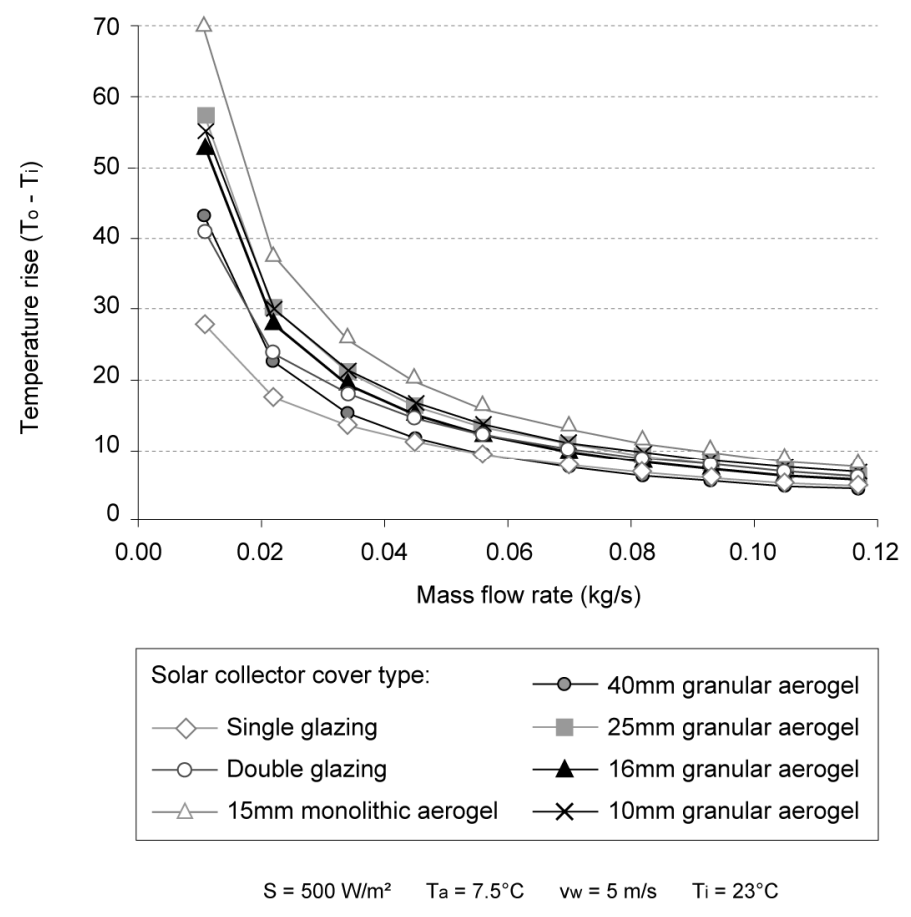

[Figure 7. Temperature rise across each collector surface]

Figure 7 displays the predicted temperature rise across the collectors at different mass flow rates. As shown, an increasing mass flow rate reduces the outlet temperature of each collector. At the lowest mass flow rate modelled, temperature rises of $28-70^{\circ} \mathrm{C}$ degrees are predicted across all collectors. Conversely, at a mass flow rate of $0.043 \mathrm{~kg} / \mathrm{s}$, as modelled in Figure 5, temperature rises of $12-20^{\circ} \mathrm{C}$ degrees are predicted. In each case, the monolithic aerogel cover provides the highest temperature rise, whereas the single glazed cover achieves the lowest, until mass flow rates are increased above $0.050 \mathrm{~kg} / \mathrm{s}$. Note that some temperatures such as those predicted for the $10 \mathrm{~mm}$ and $25 \mathrm{~mm}$ granular aerogel collectors appear to almost trace each other, despite their differing efficiencies, particularly at higher mass flow rates. However, upon close inspection, comparing the values with Figure 6 demonstrates a good correlation between both sets of results accounting for convergence at higher mass flow rates.

When analysing the efficiencies in Figure 5 and 6, note that these values are strongly influenced by the tilt angle of the collector, the inlet air temperature as well as the open area of the absorber sheet, all of which are not optimised in this system. As such, if efficiencies are compared to typical solar-air collectors, such as those found in Hastings and Mørck [14], the values appear low. For example, a glazed collector with a plane black painted absorber, with flow on both sides can operate at efficiencies of $15 \%-45 \%$ at different mass flow rates, compared to $23 \%-32 \%$ for the $10 \mathrm{~mm}$ granular aerogel collector [14]. Countering this, if ambient air was fed into the cavity and the plate absorption coefficient was increased to 0.9 , the steady state model gives operational efficiencies from $40 \%-60 \%$ for the $10 \mathrm{~mm}$ granular aerogel collector across the range of mass flow rates, indicating that granular aerogel can be used in high performance collector design. 


\subsection{In-situ performance}

A photograph of the constructed aerogel solar collector (containing the $40 \mathrm{~mm}$ granular aerogel cover) is shown in Figure 8. The collector is located at high level, spanning along the top floor of the south wall, avoiding overshadowing from surrounding buildings. In-situ results are presented from $14^{\text {th }}-20^{\text {th }}$ October 2011 following commissioning of air flow rates inside the dwelling. During monitoring, the building was largely unoccupied, except for periods during the $18^{\text {th }}-20^{\text {th }}$ October, when internal construction works took place, resulting in the MVHR fan 'boosting' whenever PIR sensors detect movement in the kitchen or bathrooms. No auxiliary heating was used. During testing, the blinds were closed in the living room to minimise passive solar gains.

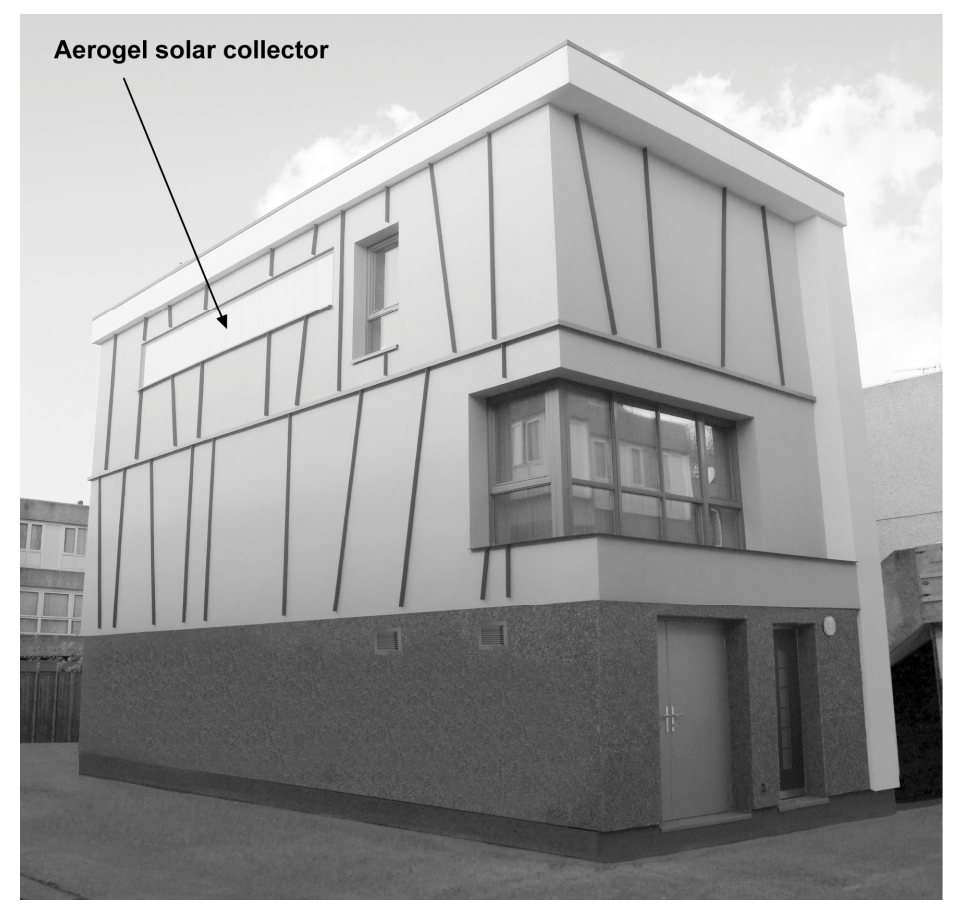

[Figure 8. South-east elevation of the retrofit house]

When analysing in-situ results, note that commissioning of air flow rates revealed significant discrepancies between air flow and static pressure measurements upstream of the collector (measured by the inlet) and downstream of the collector (measured at plant room level). At $100 \%$ fan speed ('boost' operation) the air flow downstream of the collector was $83 \mathrm{~L} / \mathrm{s}$ (static pressure $-104 \mathrm{~Pa}$ ), whereas upstream of the collector the air flow rate was $37 \mathrm{~L} / \mathrm{s}$ (static pressure of $-39 \mathrm{~Pa}$ ). Similarly at $50 \%$ fan speed ('normal' operation) the air flow downstream of the collector was $54 \mathrm{~L} / \mathrm{s}$ (static pressure $-48 \mathrm{~Pa}$ ), whereas upstream of the collector the air flow rate was $28 \mathrm{~L} / \mathrm{s}$ (static pressure -18Pa). In addition, at 50\% fan speed an air flow rate of $34.5 \mathrm{~L} / \mathrm{s}$ was measured upstream of the collector prior to the damper arrangement, indicating that 6.5 $\mathrm{L} / \mathrm{s}$ was passing through the dampers rather than being directed up towards the solar collector inlet. These pressure drops and air flow reductions were later isolated and attributed to air infiltration through drainage holes running along the bottom edge of the aluminium frame, in addition to control damper blades not sealing perfectly. Nonetheless, despite these issues, promising results were observed during the monitoring phase, as follows.

\subsection{Inlet and outlet temperatures}

Figure 9 displays the monitored inlet and outlet temperatures inside the solar collector compared to external temperature and solar irradiance. During the 7 day test period the average 
external temperature was $9.7^{\circ} \mathrm{C}$, with a maximum of $20.5^{\circ} \mathrm{C}$ occurring during the $15^{\text {th }}$ October and minimum of $1.2^{\circ} \mathrm{C}$ that night. Irradiance levels were high for the majority of the testing phase, with mostly sunny weather conditions. Minimal cloud coverage was observed on the $19^{\text {th }}$ and $20^{\text {th }}$ October, resulting in fluctuations in irradiance levels throughout the day and slightly lower daytime external temperatures. Meanwhile, relatively high cloud cover was observed between early afternoon on the $16^{\text {th }}$ and early morning on $18^{\text {th }}$ October. Significantly higher night time external temperatures of approximately $6-7^{\circ} \mathrm{C}$ were observed during this period, when compared to average night-time temperatures of $2-3^{\circ} \mathrm{C}$ during clear nights. A maximum irradiance of $940 \mathrm{~W} / \mathrm{m}^{2}$ occurred on the $18^{\text {th }}$ October at 12:40 hrs. Peak outlet temperatures ranged from $34.5^{\circ} \mathrm{C}$, measured at $10: 00 \mathrm{hrs}$ on $17^{\text {th }}$ October (a day with relatively high cloud cover) to $46.8^{\circ} \mathrm{C}$, measured at $12: 30 \mathrm{hrs}$ on $15^{\text {th }}$ October (a clear sunny day).

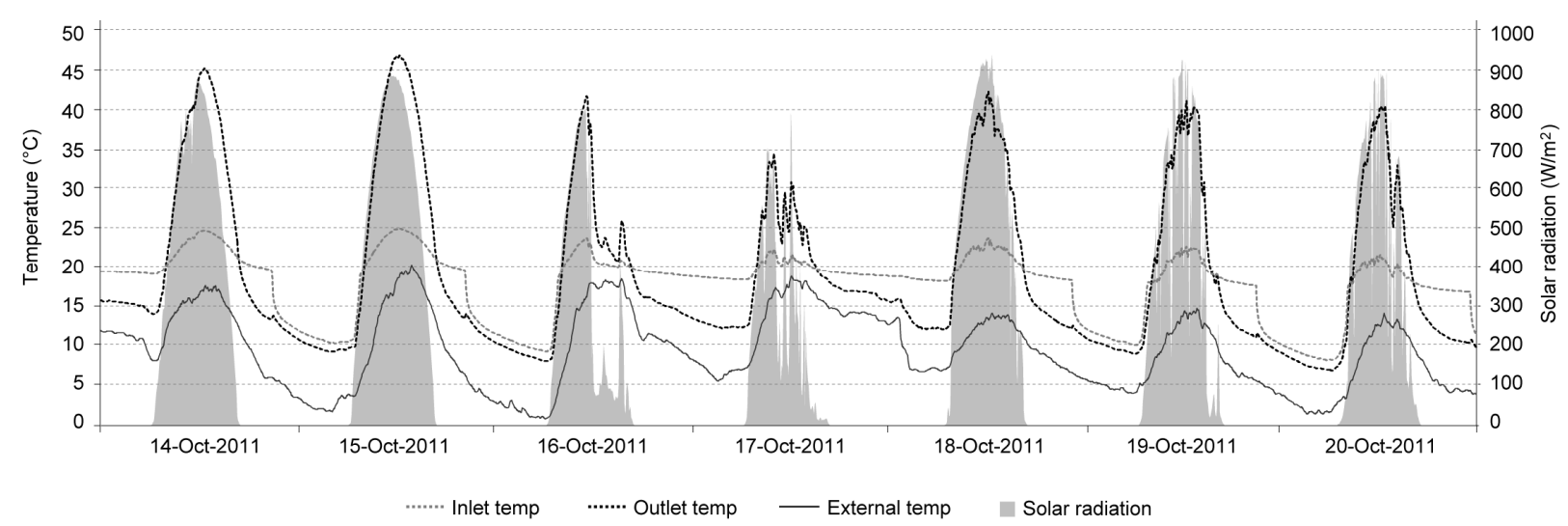

[Figure 9. Measured inlet and outlet temperature inside the collector cavity, compared to external temperature and solar irradiance during the 7 day test period]

Other points of interest in Figure 9 is that the inlet temperature increases by up to $5^{\circ} \mathrm{C}$ during the daytime, most probably due to heat gain inside the cavity. Alternatively, the sharp decreases in the inlet and outlet temperatures during the nights demonstrate that air leakages during no flow conditions have a significant impact on collector performance. Nonetheless, an average buffer of $7^{\circ} \mathrm{C}$ is found between the collector and the outside air. During the nights of the 16$17^{\text {th }}$ October, it is evident that the control remained open, indicating that the temperature difference for the damper changeover relay could be reduced to improve the system efficiency.

\subsection{Supply, extract and room temperatures}

Figure 10 displays the temperature profile of the extracted air from the kitchen and bathrooms (fed into the solar collector) and the supply air (fed to the living room and bedrooms following an indirect heat exchange between the outside air and solar collector outlet air). Peak supply temperatures (measured inside the duct leaving the plant room) from $25-30^{\circ} \mathrm{C}$ were observed during the test period. At this time, peak internal temperatures of $21.5^{\circ} \mathrm{C}$ and $21.9^{\circ} \mathrm{C}$ were monitored in the living room and bedroom respectively, indicating that the collector is capable of raising the temperature of the dwelling to comfortable levels without overheating. Comparing the living room and a north facing bedrooms temperature to the extract temperature showed a maximum temperature increases of $2.7-3^{\circ} \mathrm{C}$, respectively indicating a notable difference in the zones supplied by warm air.

When analysing Figure 10, monitored data demonstrates that the north facing bedroom is continuously warmer than the living room. During the night time, the living room is typically $1-2^{\circ} \mathrm{C}$ cooler than the bedroom. As morning approaches, the living room temperature slowly increases to reach the bedroom temperature at around noon, then dropping again towards the late evening. This behaviour is understandable since the floor area of the bedroom is $8 \mathrm{~m}^{2}$ 
making it easier to heat, compared to the living room at $21 \mathrm{~m}^{2}$. In addition, as the living room contains large areas of glazing on the South and East facades, compared to the north facing bedroom with a single window, this is expected to contribute significantly to overnight heat losses. One discrepancy that is difficult to isolate is the $1^{\circ} \mathrm{C}$ difference observed during the daytimes of the $18^{\text {th }}-20^{\text {th }}$ October, compared to the $14^{\text {th }}-17^{\text {th }}$ October. It is thought that this discrepancy is caused by workers in the house on those days walking in and out of the living room during testing, without closing doors, resulting in cooler air from the un-heated spaces circulating in that space. By comparison, little activity was expected in the bedroom on those days.

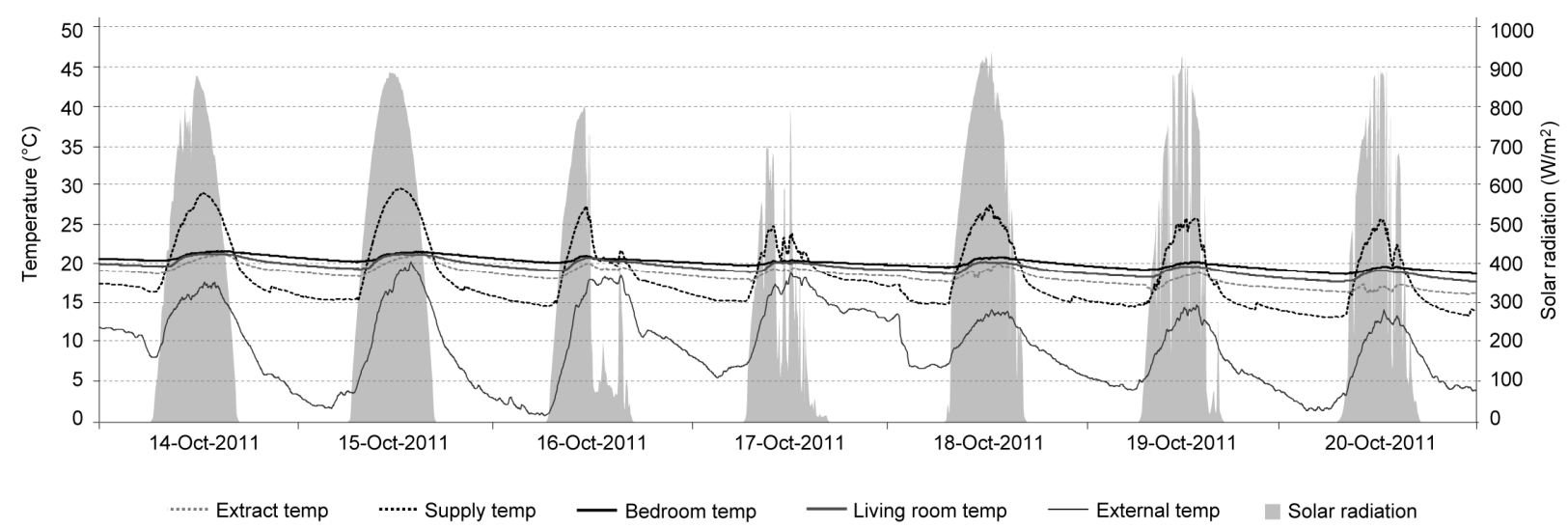

[Figure 10. Measured supply and extract temperatures, compared to the living room and north facing bedroom temperature (and external temperature and solar irradiance)]

\subsection{Temperature profile through collector}

Figure 11 displays the temperature profile through the solar collector cavity, based on the eight temperature measurements taken behind the absorber sheet (visualised earlier in Figure 1). Values are displayed for the $15^{\text {th }}$ October, a clear sunny day, as well as the $18^{\text {th }}$ October which was also clear, except for some scattered clouds late in the evening. As shown, there is a significant difference between the two sets of data. This is largely because the dwelling was occupied during the $18^{\text {th }}$ October and occupancy sensors repeatedly activated the 'boost' on the MVHR, effectively doubling the mass flow rate through the solar collector at various points throughout the day.

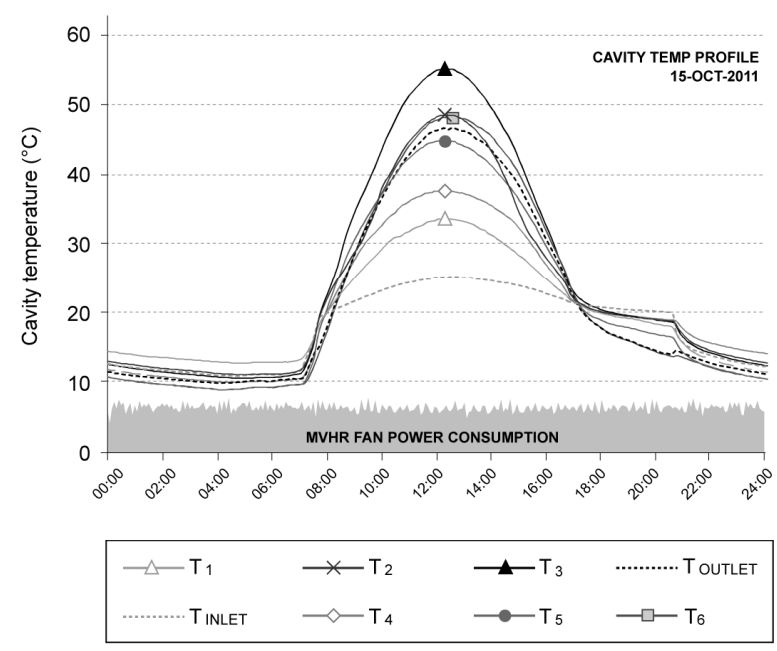

PEAK CAVITY TEMPERATURES:
\begin{tabular}{|rrrr|}
\hline $33.6^{\circ} \mathrm{C}$ & $48.6^{\circ} \mathrm{C}$ & $55.3^{\circ} \mathrm{C}$ & $46.8^{\circ} \mathrm{C}$ \\
$25.1^{\circ} \mathrm{C}$ & $37.7^{\circ} \mathrm{C}$ & $44.9^{\circ} \mathrm{C}$ & $48.4^{\circ} \mathrm{C}$ \\
\hline
\end{tabular}

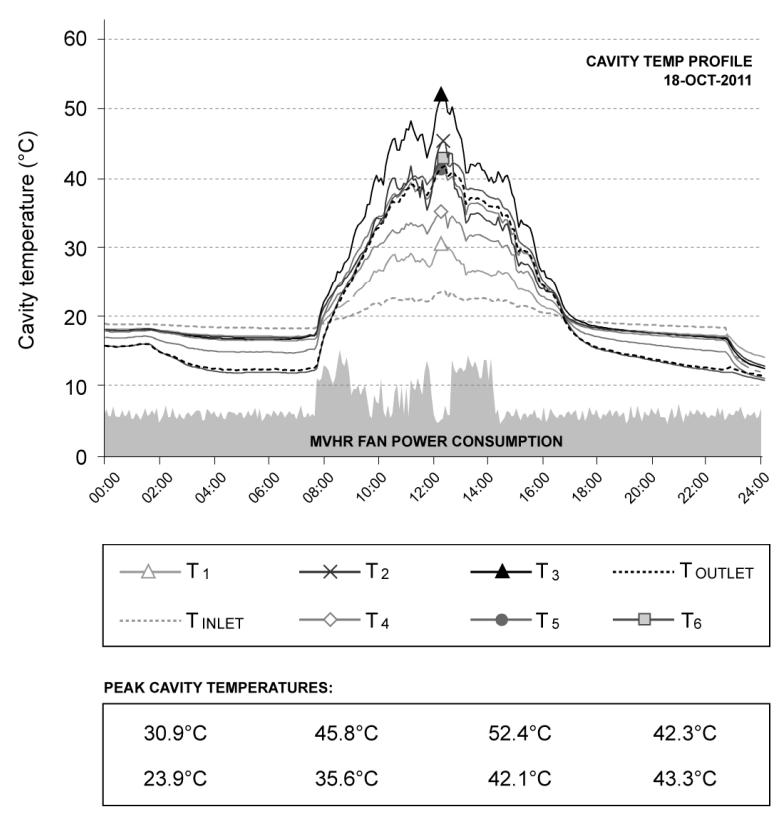


[Figure 11. Temperature profiles through the solar collector cavity. Left graph shows $15^{\text {th }}$ October with the MVHR fan running in 'normal' operation. Right graph shows $18^{\text {th }}$ October with the MVHR in 'boost' mode at various points in the day]

An indication of when boosting occurred can be established by analysing the peaks in the MVHR power use (shown at the base of each graph). As shown, sustained periods of boosting during the $18^{\text {th }}$ October occurred from 7:45-9:30 hrs, at 11:45-12:00 hrs and from 12:30-2:15 hrs. As a result, sharp temperature drops of up to $10^{\circ} \mathrm{C}$ are observed. However, the collector quickly heats up again once 'normal' flow is resumed. By comparison, the temperature profile through the cavity on the $15^{\text {th }}$ October follows a much smoother profile, with readings along the top edge being the higher than their lower counterparts. On both days, there is evidence of a 'hot spot' in the top central right zone of the cavity $\left(\mathrm{T}_{3}\right)$, up to $10^{\circ} \mathrm{C}$ hotter than the outlet in peak conditions. A similar 'hot spot' was reported by the Danish Technical Institute in a study of connectable solar collectors. Here, Jensen and Bosanac [51] claimed that the most likely cause was a less even distribution of air flow over that area.

\subsection{Validation}

In order to validate the steady state model and design parameters presented in the cover efficiency investigation, Figure 12 displays the predicted vs. measured outlet temperatures for the $15^{\text {th }}$ and $18^{\text {th }}$ October. In each case, outlet temperatures are calculated based on in-situ data for external temperature, irradiance and the inlet fluid temperature. Average mass flow rates of $0.048 \mathrm{~kg} / \mathrm{s}$ and $0.073 \mathrm{~kg} / \mathrm{s}$ are applied for the MVHR under 'normal' and 'boost' operation respectively (calculated based on average air flow rates of $41 \mathrm{~L} / \mathrm{s}$ and $60 \mathrm{~L} / \mathrm{s}$ in the commissioning report).

The impact of air infiltration and leakages has been accounted for by following a methodology to correct $\mathrm{Q}_{\mathrm{U}}$, proposed by Bernier and Plett [52]. According to Bernier and Plett [52], for collectors under negative pressure, inward infiltration can be calculated using Equation (23).

$Q_{U}=\dot{m}_{\text {average }} C p\left(T_{0}-T_{i}\right)-\left(\dot{m}_{o}-\dot{m}_{i}\right) C p\left(T_{i}-T_{a}\right)$

Conversely, for collectors under positive pressure (or no flow conditions), outward leakages can be accounted for using Equation (24).

$Q_{U}=\dot{m}_{\text {average }} C p\left(T_{0}-T_{i}\right)-\left(\dot{m}_{i}-\dot{m}_{0}\right) C p\left(T_{L}-T_{a}\right)$

In each equation, $\dot{\mathrm{m}}_{\mathrm{o}}$ and $\dot{\mathrm{m}}_{\mathrm{i}}$ refer to the measured mass flow rates at the inlet and outlet of the collector, respectively. $T_{\mathrm{L}}$ is the average temperature of air lost to the environment, estimated using $\left(\mathrm{T}_{\mathrm{i}}+\mathrm{T}_{\mathrm{o}}\right) / 2$, where $\mathrm{T}_{\mathrm{o}}$ is based on an initial estimate, corrected using an iteration loop.

In order to validate the collector outlet temperatures, it was first necessary to determine a reduction factor for leakages/infiltration, since the drop in mass flow rate was not just caused though leaks inside the collector. It was also caused through air passing through the damper blades, thus not going through the collector. Based on commissioning (at $50 \%$ fan speed), it was established that just $47.5 \mathrm{~L} / \mathrm{s}$ (of the total $54 \mathrm{~L} / \mathrm{s}$ ) was extracted from the collector as $6.5 \mathrm{~L} / \mathrm{s}$ was passing through the dampers. Of this $47.5 \mathrm{~L} / \mathrm{s}$, only $28 \mathrm{~L} / \mathrm{s}$ was measured upstream of the collector inlet, indicating that $19.5 \mathrm{~L} / \mathrm{s}$ could be attributed to infiltration. Consequently, the impact of infiltration accounted for in the validation process could be reduced by $25 \%$. Next, it was then necessary to identify the times at which air was flowing through the collector, compared to no-flow conditions. This was determined by assessing the temperature difference 
between the outlet temperature and the extract temperature from the house (based upon the control strategy outlined in Section 3). Following these steps, for each line of 5 minute experimental data, Qu is calculated assuming either a predicted 'leakage in' or 'leakage out'. The outlet temperature is then determined for each time period.
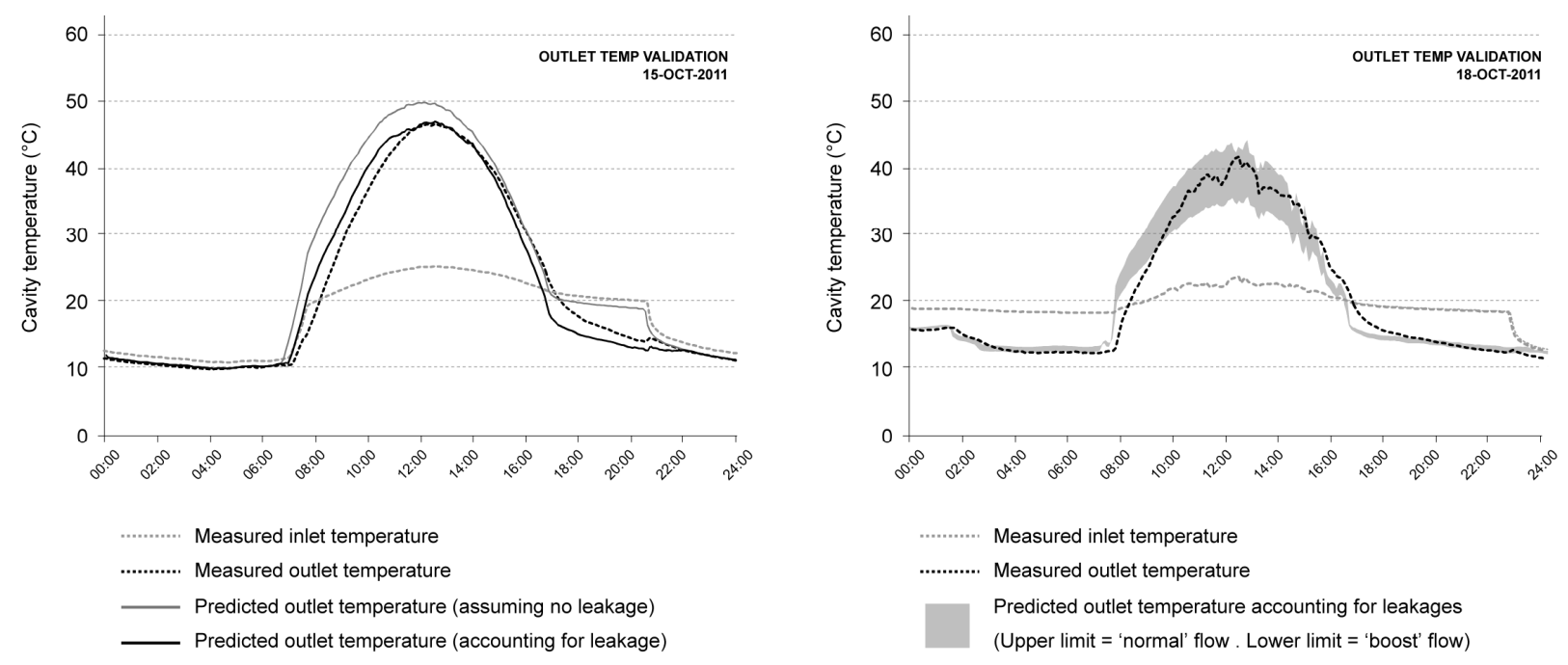

[Figure 12. Predicted vs. In-situ outlet temperatures. Left graph shows $15^{\text {th }}$ October, where the predictions assume the collector is perfectly sealed and also taking leakage into account. Right graph shows $18^{\text {th }}$ October where the outlet temperature is predicted at 'normal' and 'boost' flow rates]

Predicted outlet temperatures for the $15^{\text {th }}$ October are calculated assuming the collector is perfectly sealed and also accounting for infiltration. As shown, the peak outlet temperature is overestimated by approximately $4-5^{\circ} \mathrm{C}$ if the collector is assumed to be perfectly sealed. Furthermore, during the evening/night, the predicted outlet temperature closely follows the inlet temperature profile, since losses are assumed to be minimal. By comparison, if leakages are accounted for, the peak outlet temperature closely matches the measured value and evening/night time losses correlate much better with the measured outlet temperature. A discrepancy inherent to both calculations due to there steady state nature is the temperature lag experienced during the morning as the collector begins to heat and during the evening as it cools. Nonetheless, if $\mathrm{Q}_{\mathrm{U}}$ is calculated from the predicted outlet temperature taking losses into account, energy output is found to be within $5 \%$ of the measured value.

For October $18^{\text {th }}$, the predicted outlet temperature (taking losses into account) is calculated with an upper and lower limit to account for the MVHR switching between 'normal' and 'boost' mode respectively. As shown, the measured outlet temperature is within the allowable limits of the two flow rates modelled. Again there is a discrepancy due to lag inside the collector, not accounted for in the steady state model. Nonetheless, with the air leakages properly accounted for, the predicted and measured outlet temperatures correlate reasonably well.

\subsection{Discussion}

In-situ results have demonstrated that a solar air collector containing a translucent aerogel cover can function well in a domestic solar heating application. Despite air leakages / infiltration, the prototype successfully raised the temperature of the extract air in a mechanically ventilated dwelling up to $45^{\circ} \mathrm{C}$, providing additional energy to pre-heat the supply air up to $30^{\circ} \mathrm{C}$. Resultant internal temperatures of $21-22^{\circ} \mathrm{C}$ indicate that the prototype will play an important role in maintaining comfortable living conditions throughout the heating season. 
Although in-situ results were based on a collector with a $40 \mathrm{~mm}$ granular aerogel cover, the reasonable correlation between predicted and measured performance has gone some way towards verifying the design parameters calculated in the cover efficiency investigation.

Applying these findings, Figure 13 displays the predicted annual energy output for comparative solar air collectors with different cover types. Climate data is generated from annual hourly irradiance (on a south facing vertical surface) and external temperature data generated using the CIBSE TRY London weather file [50]. All calculations assume a constant inlet temperature of $23^{\circ} \mathrm{C}$ and mass flow rate of $0.048 \mathrm{~kg} / \mathrm{s}$. In each case, collectors are assumed to be built completely air tight. To isolate the benefits of the collector from the standard MVHR operation, calculations only count the energy output if the collector outlet temperature is higher than the inlet temperature. Alternatively, the MVHRs summer bypass function is assumed to be operational, discounting the energy output if the external temperature exceeds $20^{\circ} \mathrm{C}$. All calculated outputs are reduced by $5 \%$ to account for discrepancies observed in the steady state model.
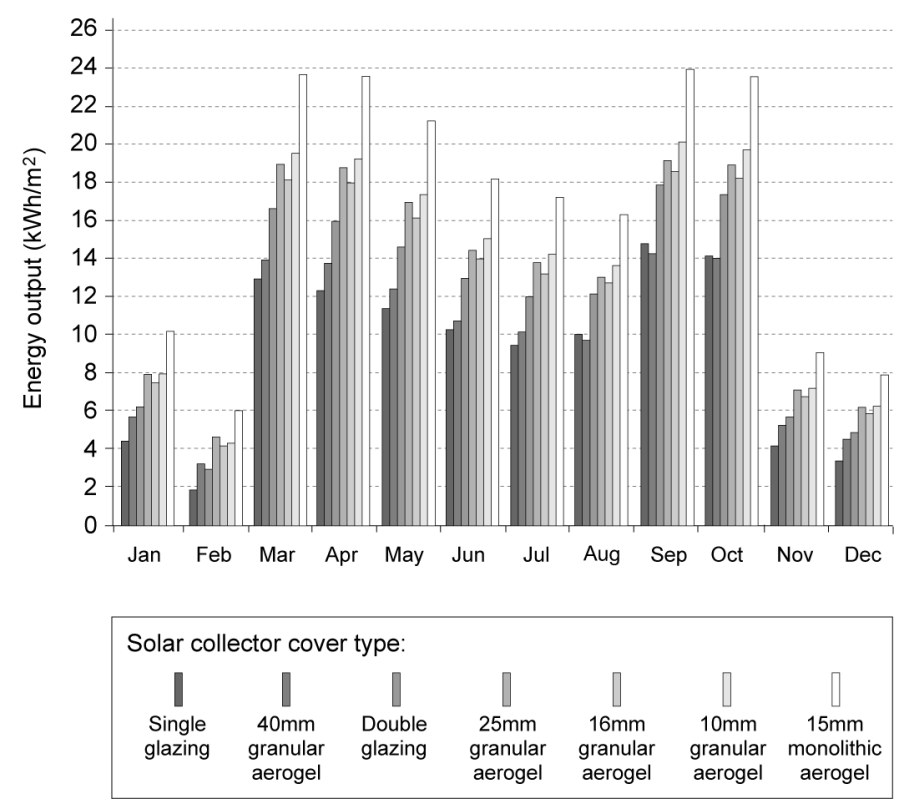

[Figure 13. Predicted annual energy output for solar collector types]

Predicted annual energy outputs range from $110 \mathrm{kWh} / \mathrm{m}^{2} /$ year for the single glazed collector to $202 \mathrm{kWh} / \mathrm{m}^{2} /$ year for the monolithic aerogel cover. Energy outputs for the granular aerogel systems are $118 \mathrm{kWh} / \mathrm{m}^{2} /$ year with the $40 \mathrm{~mm}$ cover, $161 \mathrm{kWh} / \mathrm{m}^{2} /$ year with the $25 \mathrm{~mm}$ cover, $154 \mathrm{kWh} / \mathrm{m}^{2} /$ year with the $16 \mathrm{~mm}$ cover and $166 \mathrm{kWh} / \mathrm{m}^{2} /$ year with the $10 \mathrm{~mm}$ cover. The double glazed collector has a predicted energy output of $140 \mathrm{kWh} / \mathrm{m}^{2} /$ year. For each case, the largest savings are estimated during the midseason, when heating is required and incident radiation levels are high. By comparison, benefits can be obtained even during the coldest months.

Utilising these annual energy outputs, Figure 14 displays a predicted payback curve for each collector type. To avoid uncertainties regarding fabric performance, auxilary heating systems and occupancy usage, which must be dealt with on a case-by-case basis, payback calculations assume that the collector output is offsetting an automated electric heating coil in an MVHR system. The baseline cost of electricity is assumed to be $£ 0.12 / \mathrm{kWh}(€ 0.145 / \mathrm{kWh})$, with a $6 \%$ annual fuel price inflation rate and $2 \%$ discount interest rate applied. The capital costs for each cover type is based on sales costs obtained through personal communication with R. Lowe (01 
November 2011) from Xtralite Ltd. These costs were $£ 190 / \mathrm{m}^{2}, £ 160 / \mathrm{m}^{2}, £ 143 / \mathrm{m}^{2}$ and $£ 100 / \mathrm{m}^{2}$ $\left(€ 229 / \mathrm{m}^{2}, € 193 / \mathrm{m}^{2}, € 173 / \mathrm{m}^{2}, € 121 / \mathrm{m}^{2}\right.$ ) for the $40 \mathrm{~mm}, 25 \mathrm{~mm} 16 \mathrm{~mm}$ and $10 \mathrm{~mm}$ polycarbonate panels filled with granular aerogel respectively. The single and double glazed covers were estimated at $£ 60 / \mathrm{m}^{2}$ and $£ 120 / \mathrm{m}^{2}\left(€ 72 / \mathrm{m}^{2}\right.$ and $\left.€ 145 / \mathrm{m}^{2}\right)$ respectively. A speculative cost of $£ 350 / \mathrm{m}^{2}\left(€ 422 / \mathrm{m}^{2}\right)$ was given to the $15 \mathrm{~mm}$ monolithic aerogel cover (not available commercially). Based on this investigation an additional cost of $£ 120 / \mathrm{m}^{2}\left(€ 145 / \mathrm{m}^{2}\right)$ was applied to account for the timber and aluminium framing as well as the perforated absorber sheet.

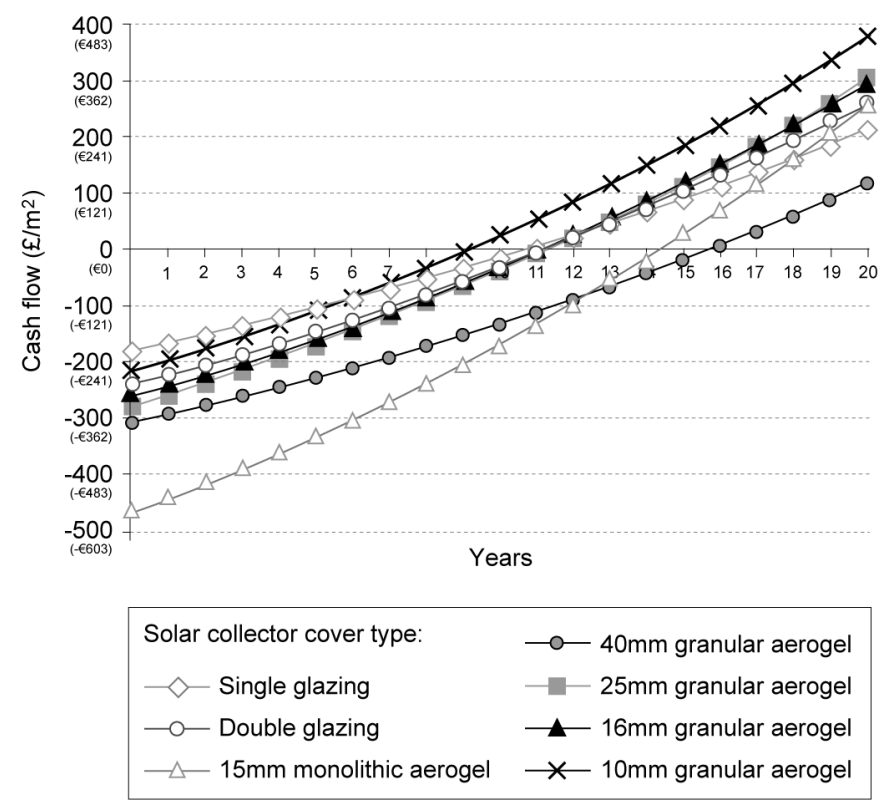

[Figure 14. Predicted payback periods for solar collector types]

According to the payback calculations, all solar collectors provide a return on investment within 9-16 years. The fastest payback is obtained from the $10 \mathrm{~mm}$ granular aerogel system, followed by the $25 \mathrm{~mm}$ and $16 \mathrm{~mm}$ systems and both conventional glazed collectors with 11 year estimated payback periods. Interestingly, the $40 \mathrm{~mm}$ granular aerogel system and the monolithic aerogel collector have longer payback periods at 14 and 16 years respectively. Evidently, if future systems are designed with granular aerogel it is unnecessary to utilise cover thicknesses above $25 \mathrm{~mm}$ unless the solar transmittance can be improved. Furthermore, if it becomes commercially available, the cost of a monolithic aerogel must be considerably less than estimated here for it to be cost effective.

Take note, the aforementioned payback calculations (per $\mathrm{m}^{2}$ of collector) do not include the fixed cost of controls, which were $£ 40$ (€48) for the temperature differential electronic thermostat with thermistors, and $£ 510$ (€615) for the three dampers with spring return actuators. An additional cost of $£ 120(€ 145)$ incurred for the 'optional summer bypass' on the MVHR was not included. If all of these costs are taken into account then payback periods (for a $5.4 \mathrm{~m}^{2}$ collector) increase from to 9-16 years to 14-21 years across all solar collector types. Alternatively, if it is assumed that just one damper with spring return actuator is used to control air flow and the MVHR summer bypass switch was specified independently of the solar collector (thus not included in the payback calculation), then payback periods can be reduced to 10-17 years, which is more acceptable. Countering these costs, if it were assumed that solar air collectors were eligible to the $£ 0.085 / \mathrm{kWh}(€ 0.103 / \mathrm{kWh})$ generation tariff under the governments Renewable Heat Incentive [53], which domestic hot water solar thermal panels 
currently obtain, then paybacks can be reduced to 7-13 years. Evidently, even with the cost of controls included, it is possible to develop an economically viable technology.

\subsection{Conclusion}

This paper has demonstrated that incorporating granular aerogel into flat plate solar air collectors can result in improved working efficiencies over conventional glazed systems. Due to the issues regarding fragility, manufacturing difficulties, availability and the perceived higher cost of monolithic aerogel, encapsulated granular aerogel can be viewed as the preferred cover material to develop novel solar technologies such as solar air heaters, solar water heaters, and solar Trombe walls.

Long term evaluation of the aerogel solar collector prototype, incorporating the $40 \mathrm{~mm}$ thick cover, with leakages mended, will be conducted as part of a two year monitoring scheme funded through the Retrofit for the Future project. Once occupied, the areas of interest will include annual thermal comfort levels inside the house, the use of auxiliary heating, particularly on cold sunny days, and the effect of moisture from the kitchen and bathrooms inside the cavity. The contributions provided by the solar collector will be assessed against the property's total gas and electricity consumption, whilst being benchmarked against other renewable technologies. The overall aim of the refurbishment is to reduce the properties baseline $\mathrm{CO}_{2}$ emissions by $80 \%$.

At the start of this refurbishment, the design team and client were keen to use this house as a novel test-rig for new technologies. Consequently, one factor that is yet to be established is the long-term durability of this prototype compared to conventional glazed solar collectors. Under normal usage as a facade component for day lighting, the aerogel filled polycarbonate panels and aluminium support systems would possess a 15 year warranty against yellowing, light transmission and thermal degradation [44]. Alone, the aerogel granules are not expected to degrade during the foreseeable life of the solar collector. In addition, since silica is inert, the aerogel can last the life of a structure and be recycled when the building is decommissioned [44]. Instead, key areas where degradation may occur include the seals, connections and fixtures supporting the cover system and framing, due to expansion and contraction of components during summertime, general wear from wind and rain exposure, and moisture build-up inside the cavity. A further issue is the integrity of the MVHR, bypass controls and dampers in the plant room. Understandably, it is imperative that this product be systematically evaluated over its operational lifespan. If developed into a market ready solution, a minimum lifespan of 15 years would be required to justify the life cycle costs.

Take note that the prototype reported in this paper was incorporated into the 'extract' side of the mechanical ventilation system due the design team not wanting to pass the dwelling's fresh air supply through a prototype which had not been tested before. Consequently, there are opportunities to improve the overall efficiency of this system by passing ambient air into the cavity and by connecting it directly to the supply air side. Furthermore, the plate absorption coefficient could feasibly be increased to 0.9 . Applying these changes to the steady state model gives operational efficiencies of up to $60 \%$ for a $10 \mathrm{~mm}$ granular aerogel collector, comparable to the results of Nordgaard and Beckman [39] and Svendsen [38], and hypotheses of Ortjohann [40] and Reim et al [42]. According to our model, the predicted annual energy output for this system is $355 \mathrm{kWh} / \mathrm{m}^{2} /$ year with a payback as low as 4.5 years.

Further efficiency improvements could be achieved through incorporating thermal storage into the cavity or by connecting the collector outlet to an air-water heat exchanger during the summertime to avoid wasting heat. There is a need to refurbish our existing building stock to 
achieve energy efficiency standards, going beyond the limitations of conventional measures. Findings from this paper aim to contribute towards this challenge.

\section{Acknowledgements}

The corresponding author would like to thank the EPSRC, Brunel University, Buro Happold Ltd and the Technology Strategy Board for funding this research project. Further thanks go to Gallions Housing Association, Fraser Brown McKenna architects, Martin Associates surveyors, Axis Europe, Xtralite, Permarock and Nuaire for their contributions during this innovative and challenging refurbishment.

All technical drawings for this prototype were drawn by the corresponding author, with support from C Biggs (Technical Director of Nuaire), J Richings (Technical Director of Permarock) and R Lowe (Technical Services Manager at Xtralite) when selecting suitable components and fixings. The system was installed by Axis Europe, the lead contractors undertaking the refurbishment. Specialist items such as the granular aerogel panels and its framing were supplied and installed by Xtralite.

\section{References}

[1] Climate Change Act, Carbon Targeting and Budgeting, Chapter 27, Part 1 - The Target for 2050, Her Majesty's Stationery Office Limited, UK, 2008.

[2] J. Ravetz, What do we know about Existing Buildings and their Future Prospects? Energy Policy 36 (2008) 4462-4470.

[3] A. Power, Does Demolition or Refurbishment of Old and Inefficient Homes Help to Increase our Environmental, Social and Economic Viability? Energy Policy 36 (2008) 44874501.

[4] S.H. Hong, T. Oreszczyn, I. Ridley, the Warm Front Study Group, The Impact of Energy Efficient Refurbishment on the Space Heating Fuel Consumption in English Dwellings, Energy and Buildings 38 (2006) 1171-1181

[5] International Energy Agency, Solar Renovation Concepts and Systems - A Report of Task 20 Subtask F, Solar Heating and Cooling Programme, 1999.

[6] J.O. Dalenbäck, Solar Energy in Building Renovation, Energy and Buildings 24 (1996) 3950

[7] K. Voss, Solar Energy in Building Renovation - Results and Experience of International Demonstration Buildings, Energy and Buildings 32 (2000) 291-302

[8] A.K. Athienitis, H. Ramadan, Numerical Model of a Building with Transparent Insulation, Solar Energy 67 (1999) 101-109.

[9] H. Suehrcke, D. Däldehög, J.A. Harris, R.W. Lowe, Heat Transfer Across Corrugated Sheets and Honeycomb Transparent Insulation, Solar Energy 76 (2004) 351-358

[10] P. Dolley, C. Martin, M. Watson, Performance of Walls Clad with Transparent Insulation Material in Realistic Operation, Building and Environment 29 (1994) 83-88. 
[11] B. Peuportier, J. Michel, Comparative Analysis of Active and Passive Solar Heating Systems with Transparent Insulation, Solar Energy 54 (1995) 13-18.

[12] N.D. Kaushika, K. Sumathy, Solar Transparent Insulation Materials: A Review, Renewable and Sustainable Energy Reviews 7 (2003) 317-351.

[13] I.L. Wong, P.C. Eames, R.S. Perera, A Review of Transparent Insulation Systems and the Evaluation of Payback Period for Building Applications, Solar Energy 81 (2007) 1058-1071.

[14] R.S. Hastings, O Mørck, Solar Air Systems - A Design Handbook, first ed., James \& James, London, UK, 2000.

[15] M. Rommel, A. Wagner, Application of Transparent Insulation Materials in Improved Flat-Plate Collectors and Integrated Collector Storage System, Solar Energy 49 (1992) 371380 .

[16] C.H. Schmidt, A. Goetzberger, J. Schmid, Test Results and Evaluation of Integrated Collector Storage Systems with Transparent Insulation, Solar Energy 41 (1988) 487-494.

[17] N.D. Kaushika, K.S. Reddy, Thermal Design and Field Experiment of Transparent Honeycomb Insulated Integrated-Collector-Storage Solar Water Heater, Applied Thermal Engineering 19 (1999) 145-161.

[18] Okalux Kapipane, Okalux, Retrieved January 17, 2012, from http://www.miltyr.se/Okalux_Downloads/3-Okapane/i_kapipane twd_pmma_e.pdf

[19] W.J. Platzer, A. Goetzberger, Recent Advances in Transparent Insulation Technology, Transparent Insulation - TI8, Fraunhofer-Institute for Solar Energy Systems, Freiburg, Germany, 2004.

[20] M. Dowson, D. Harrison, S. Craig, Z. Gill, Improving the Thermal Performance of SingleGlazed Windows using Translucent Granular Aerogel, International Journal of Sustainable Engineering 4 (2011) 266-280.

[21] W.J. Platzer, Solar Transmission of Transparent Insulation Material, Solar Energy Materials 16 (1987) 275-287.

[22] J. Fricke, T. Tillotson, Aerogels: Production, Characterization and Applications, Journal of Thin Solid Films 297 (1997) 212-223.

[23] F. Schwertfeger, D. Frank, M. Schmidt, Hydrophobic Waterglass Based Aerogels without Solvent Exchange or Supercritical Drying, Journal of Non-Crystalline Solids 225 (1998) 24-29.

[24] L.D. Shorrock, J. Henderson, J.I. Utley, Reducing Carbon Emissions from the UK Housing Stock, BRE Press, Watford, UK, 2005.

[25] M. Dowson, M. Grogan, T. Birks, D. Harrison, S. Craig, Streamlined Life Cycle Assessment of Transparent Silica Aerogel made by Supercritical Drying, Applied Energy (2011) doi:10.1016/j.apenergy.2011.11.047 
[26] M. Van Bommel, A. De Haan, Drying of Silica Aerogel with Supercritical Carbon Dioxide, Non-Crystalline Solids 186 (1995) 78-82.

[27] R.T. Bynum, Insulation Handbook, first ed., McGraw-Hill, New York, USA, 2001.

[28] A. Soleimani-Dorcheh, M.H. Abbasi, Silica Aerogel - Synthesis, Properties and Characterization, Materials Processing Technology 199 (2008) 10-26

[29] R. Baetens, B. Petter-Jelle, A. Gustavsend, Aerogel Insulation for Building Applications: A State-of-the-Art Review, Energy and Buildings 43 (2011) 761-769

[30] B. Petter-Jelle, Traditional, State-of-the-art and Future Thermal Building Insulation Materials and Solutions - Properties, Requirements and Possibilities, Energy and Buildings 43 (2011) 2549-2563

[31] H. Yokogawa, Thermal Conductivity of Silica Aerogels, in: S. Sakka, Handbook of SolGel Science \& Technology, Vol 2., Kluwer Academic Publishers, New York, USA, 2005, pp. 265-272.

[32] Cabot Corporation, Aerogel for Insulation, Daylighting, Additives, Retrieved February 28, 2011, from http://www.cabot-corp.com/Aerogel

[33] M. Rubin, C.M. Lampert, Transparent Silica Aerogels for Window Insulation, Solar Energy Materials 7 (1983) 393-400

[34] Cabot Corporation, Cabot Nanogel Promises Unmatched Energy Savings - Revolutionary Insulating Material makes the Best Window, Wall and Skylight Products Better, Journal of Pigment \& Resin Technology 33 (2004) pp 345.

[35] M. Werner, L. Brand, Focus Report 2010. Aerogels, General Sector Reports, Chemistry and Materials, ObservatoryNANO, p12, 2010.

[36] J. Fricke, Aerogels, Scientific American 258 (1988) 92-97

[37] R. Caps, J. Fricke, Fibrous Insulations with Transparent Cover for Passive Use of Solar Energy, Thermophysics 10 (1989) 493-504.

[38] S. Svendsen, Solar Collector with Monolithic Silica Aerogel, Non-Crystalline Solids 145 (1992) 240-243

[39] A. Nordgaard, W.A Beckman, Modelling of Flat-Plate Collectors based on Monolithic Silica Aerogel, Solar Energy 49 (1992) 387-402.

[40] J. Ortjohann, Granular Aerogel for the Use in Solar Thermal Collectors, ISES 2001 Solar World Congress

[41] V. Wittwer, Development of aerogel windows. Journal of Non-Crystalline Solids 145 (1992) 233-236 
[42] M. Reim, W. Körner, J. Manara, S. Korder, M. Arduini-Schuster, H.P Ebert, J. Frike, Silica aerogel granulate material for thermal insulation and daylighting, Solar Energy 79 (2005) 131-139

[43] Building Research Establishment (BRE), Passivhaus Primer, 2010, Supported Energy Saving Trust and Passiv Haus Institut, Retrieved January 12, 2012, from http://www.passivhaus.org.uk/filelibrary/Passivhaus\%20Standards/BRE_Passivhaus_Primer.pd $\underline{\mathrm{f}}$

[44] Cabot Corporation, Facade Systems with Nanogel, Cabot Corporation \& Roda, Retrieved November 1, 2010, from http://www.cabot-corp.com/wcm/download/enus/ae/facade $\% 20$ systems $\% 20$ roda.pdf

[45] J.A. Duffie, W.A. Beckman, Solar Engineering of Thermal Processes, third ed., John Wiley \& Sons Inc, New Jersey, USA, 2006.

[46] B. Parker, Derivation of Efficiency and Loss Factors for Solar Air Heaters", Solar Energy 26 (1981) 27-32

[47] Lexan., Daylighting, Polycarbonate filled with Nanogel, Amerilux, 2001, Retrieved February 28, 2011, from

http://www.ameriluxinternational.com/html/architectData/nanogel/documents/nanogelData.pdf

[48] J.M. Schultz, K.I. Jensen, Evacuated Aerogel Glazings, Vacuum 82 (2008) 723-729.

[49] Vesma., UK Monthly and Weekly Degree Day Figures, 2009. Retrieved June 2009, from http://www.vesma.com/ddd/index.htm

[50] Chartered Institute of Building Services Engineers, CIBSE TRY Hourly Weather Data Set - London, Test Reference Year from 1983-2004 data sets.

[51] S.Ø. Jensen, M. Bosanac, Connectable Solar Air Collectors, SEC-R-22, Solar Energy Centre Denmark, Danish Technological Institute, Denmark, 2002.

[52] M.A. Bernier, E.G. Plett, Thermal Performance Representation and Testing of Air Solar Collectors, Solar Energy Engineering 110 (1988) 74-81.

[53] Renewable Heat Incentive, Tariff Level Tables | RH Incentive, Retrieved November 28, 2011, from http://www.rhincentive.co.uk/eligible/levels/ 